\title{
Influences of Catchment and River Channel Characteristics on the Magnitude and Dynamics of Storage and Re-Suspension of Fine Sediments in River Beds
}

\author{
Jungsu Park ${ }^{1, *}$, Ramon J. Batalla ${ }^{2,3,4}$, Francois Birgand ${ }^{5}$, Michel Esteves ${ }^{6}$, Francesco Gentile ${ }^{7} \mathbb{D}$, \\ Joseph R. Harrington ${ }^{8}$, Oldrich Navratil ${ }^{9}$, Jose Andres López-Tarazón 2,10,11,12 $\mathbb{D}$ and \\ Damià Vericat 2,13
}

1 K-water Research Institute, Korea Water Resources Corporation (K-water), 200 Sintanjin-Ro, Daedeok-Gu, Daejeon 34350, Korea

2 Fluvial Dynamics Research Group, Department of Environment and Soil Sciences, University of Lleida, Plaça de Víctor Siurana, 1, 25003 Lleida, Spain; rbatalla@macs.udl.cat (R.J.B.); ja.lopez@uib.cat (J.A.L.-T.); dvericat@macs.udl.cat (D.V.)

3 Catalan Institute for Water Research (ICRA), 17003 Girona, Spain

4 Faculty of Forest Sciences and Natural Resources, Universidad Austral de Chile, Independencia 631, Valdivia, Región de los Ríos, Chile

5 Department of Biological and Agricultural Engineering, North Carolina State University, Raleigh, NC 27695, USA; birgand@ncsu.edu

6 Institute for Geosciences and Environmental Research (IGE)-University Grenoble Alpes/IRD, 621 Avenue Centrale, 38400 Saint-Martin-d'Hères, France; michel.esteves@ird.fr

7 Department of Agricultural and Environmental Science, University of Bari Aldo Moro, 70126 Bari, Italy; francesco.gentile@uniba.it

8 School of Building \& Civil Engineering, Cork Institute of Technology, Rossa Ave, Bishopstown, T12 P928 Cork, Ireland; joe.harrington@cit.ie

9 School of Building and Society, University of Lyon, 92 Rue Pasteur, 69007 Lyon, France; oldrich.navratil@univ-lyon2.fr

10 Mediterranean Ecogeomorphological and Hydrological Connectivity Research Team, Department of Geography, University of the Balearic Islands, Carretera de Valldemossa, km 7.5, 07122 Palma, Spain

11 Institute of Agro-Environmental and Water Economy Research, INAGEA, University of the Balearic Islands Carretera de Valldemossa, km 7.5, 07122 Palma, Spain

12 Institute of Earth and Environmental Science, University of Potsdam, Am Neuen Palais 10, 14469 Potsdam, Germany

13 Forest Sciences and Technology Centre of Catalonia, Carrer de Sant Llorenç, 0, 25280 Solsona, Spain

* Correspondence: pjs7731@kwater.or.kr; Tel.: +82-42-629-4732

Received: 14 March 2019; Accepted: 24 April 2019; Published: 26 April 2019

\begin{abstract}
Fine particles or sediments are one of the important variables that should be considered for the proper management of water quality and aquatic ecosystems. In the present study, the effect of catchment characteristics on the performance of an already developed model for the estimation of fine sediments dynamics between the water column and sediment bed was tested, using 13 catchments distributed worldwide. The model was calibrated to determine two optimal model parameters. The first is the filtration parameter, which represents the filtration of fine sediments through pores of the stream bed during the recession period of a flood event. The second parameter is the bed erosion parameter that represents the active layer, directly related to the re-suspension of fine sediments during a flood event. A dependency of the filtration parameter with the catchment area was observed in catchments smaller than $\sim 100 \mathrm{~km}^{2}$, whereas no particular relationship was observed for larger catchments $\left(>100 \mathrm{~km}^{2}\right)$. In contrast, the bed erosion parameter does not show a noticeable dependency
\end{abstract}


with the area or other environmental characteristics. The model estimated the mass of fine sediments released from the sediment bed to the water column during flood events in the 13 catchments within $\sim 23 \%$ bias.

Keywords: bed erosion; catchment area; filtration; sediment accumulation; sediment bed fluidization; sediment re-suspension

\section{Introduction}

Fine particles or sediments are considered one of the most important factors affecting the quality and functioning of fluvial environments. For instance, fine sediments are long-lasting sources of toxic substances in catchments; that is, contaminants, such as pathogens, heavy metals as well as nutrients, are transported attached to fine sediments [1-5]. Fine sediment dynamics also have various effects on the health of benthic communities and the overall aquatic ecosystems [6-9].

The suspended sediment yield is affected by various catchment characteristics such as climate, geology, soils, catchment area, and land cover [10-12]. Because of the spatial variability of these catchment characteristics, developing a universally applicable fine sediment transport model remains an important research challenge. Rainfall intensity, erodibility and runoff processes mainly govern the fine sediment dynamics at the basin outlet. Not only these factors but also the catchment sizes cause variations in the sediment supply and transport processes. For example,

Gao et al. [13] suggested that the suspended sediment load $\left(Q_{s}\right)$ is dominated by short-time-interval processes in smaller catchments with less-developed drainage density and small capacity to store fine sediment (i.e., drainage area $<0.1 \mathrm{~km}^{2}$ ). As the drainage area increases, the homogeneity of the catchment decreases and drainage density gradually increases, leading to a greater contribution of remobilization of fine riverbed sediments and bank erosion to the overall sediment budget [13].

Suspended sediment concentration (hereafter $C$ ) is closely related to flow discharge $(Q)$, but this relationship varies over time, from the flood scale to the annual scale. The $\mathrm{C}-\mathrm{Q}$ relationship often shows orders of magnitude of scatter [14]. Such variability is explained by the fact that the rising limb of the flood generally shows a different $C-Q$ relationship compared with the falling limb, leading to a hysteresis pattern in the relationship [13,15-19]. The supply of sediment from the channel system is often considered to be a significant source of sediment [18,20-22]. For instance, Klein [17] observed clockwise hysteresis, being mainly driven by the supply of sediments from the channel bed or from highly eroded hillslopes close to the outlet. In contrast, anticlockwise hysteresis can be observed when sediment is supplied from distant upstream sources. Recently, Yang et al. [23] derived a flow and sediment travel time model, verifying that clockwise hysteresis is observed when flow travel time is more extended than the sediment travel time, whereas anticlockwise hysteresis is observed in the opposite. More recently, Juez et al. [24], based in a series of laboratory tests, observed clockwise hysteresis driven by the supply of sediment from the channel bed, whereas anticlockwise hysteresis is observed when upstream supply of sediment has more contribution. These hysteresis patterns are one of the main reasons why single power-law models are generally insufficient to explain the scatter in the relationship between $C$ and $Q[14,25]$. Seasonality of precipitation and land cover also causes scatter in C for a given Q [15,26-28]. For example, Alexandrov et al. [15] carried out a study in a semi-arid region and observed that autumn-spring convective storms with higher-intensity rainfall often produce higher $\mathrm{C}$ than winter frontal storms with lower intensity; much earlier,

Negev [26] and more recently Cantalice et al. [21] have suggested that the first flood in a given water year could have a higher $C$ than subsequent floods of similar magnitude. The reason of these differences was attributed to the re-suspension of deposited sediment from bed during the first flood of the year. Seasonal variations of the flow due to snowmelt may also induce additional sediment supply from the channel bed and cause variations in the functional relationship between $C$ and $Q$. 
Stubblefield et al. [29] observed an increase of the sediment supply from the channel bed when the flow rate was increased by snowmelt in a field study of Lake Tahoe. Interannual variations of the suspended sediment load with water discharge are also caused by larger-scale variations of the environment, such as climatic changes and related variability of discharge [30], or extreme events such as large floods [14].

A conceptual model coupling fine sediment dynamics with bedload transport was presented by Park and Hunt [31] based on systematic analysis of fine sediment and stream bed movement. This study led to the development of a model for the estimation of fine sediment accumulation and re-suspension from the bed [32]. It is worth mentioning that fine sediments are defined as "particles that are transported in suspension in surface waters and can also be accumulated in the sediment beds" [32]. Within this context, the objective of this study is (i) to analyze the applicability and robustness of the model developed by Park et al. [32] and (ii) to study the effect of catchment characteristics (e.g., catchment area, climate) on the performance of the model. The study was carried out based on data of 13 catchments with different drainage area and located in various hydro-climatic environments.

\section{Materials and Methods}

\subsection{Research Sites and Data Sources}

$\mathrm{C}$ and $\mathrm{Q}$ data from 13 catchments (ranging from 2.2 to $21,000 \mathrm{~km}^{2}$ ) were used to test the robustness of the model under different environmental characteristics (Figure 1; Table 1; Table S1 in Supplementary Materials). Note that we consider environmental characteristics, as mainly, the catchment area and climatic condition of catchments.
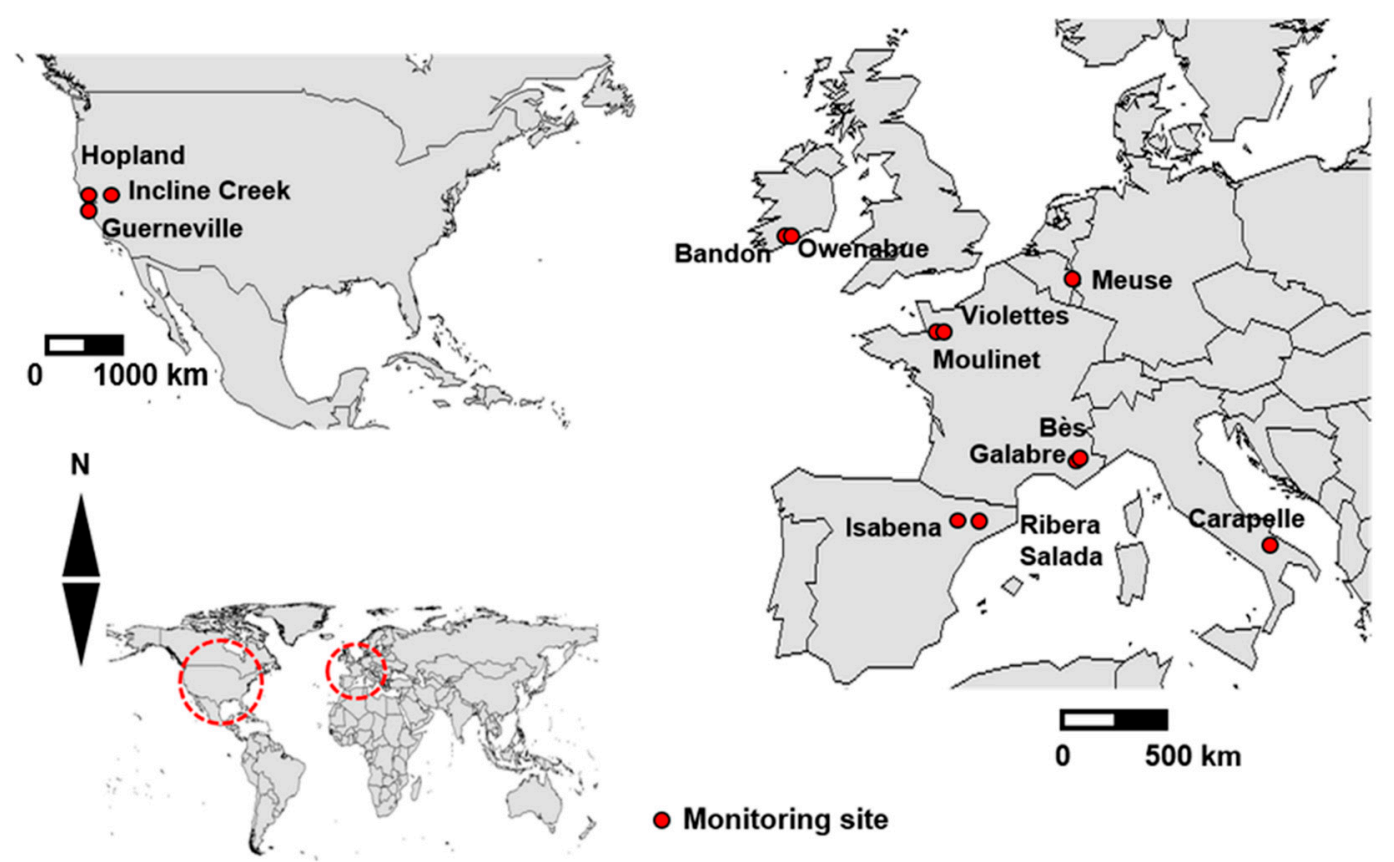

- Monitoring site

Figure 1. Location of the monitoring sites (see Table 1 and Table $\mathrm{S} 1$ for details of the catchments). 
Table 1. Characteristics of the studied catchments and model parameters.

\begin{tabular}{|c|c|c|c|c|c|c|c|c|c|c|c|c|c|}
\hline \multirow[b]{2}{*}{ No } & & & \multirow{2}{*}{$\begin{array}{l}\text { Catchment } \\
\text { Area } \\
\left(\mathrm{km}^{2}\right)\end{array}$} & \multirow[b]{2}{*}{ Climate } & \multirow{2}{*}{$\begin{array}{l}\text { Mean Annual } \\
\text { Precipitation } \\
\text { (mm) }\end{array}$} & \multirow{2}{*}{$\begin{array}{c}\text { Dominant Bed } \\
\text { Surface } \\
\text { Materials }\end{array}$} & \multicolumn{2}{|c|}{ Observation } & \multirow{2}{*}{$\underset{\left(\mathrm{m}^{3} / \mathrm{s}\right)}{\mathrm{Q}_{\mathrm{c}}}$} & \multirow{2}{*}{$\underset{\left(\mathrm{m}^{3} / \mathrm{s}\right)}{\mathrm{Q}_{\max }}$} & \multirow{2}{*}{$\begin{array}{l}\text { Background } \\
\text { C }\left(C_{b}\right)\end{array}$} & \multirow{2}{*}{$\begin{array}{l}\mathbf{M}_{\max } \\
(\mathrm{Mg})\end{array}$} & \multirow[b]{2}{*}{ References } \\
\hline & Sit & & & & & & Period & $\begin{array}{l}\text { Frequency } \\
\text { (min) }\end{array}$ & & & & & \\
\hline 1 & Violettes & France & 2.2 & $\begin{array}{c}\text { Temperate } \\
\text { oceanic }\end{array}$ & 900 & Silty loess & $\begin{array}{c}1 \text { June 2002-31 May } \\
2003\end{array}$ & 10 & 0.05 & 0.15 & 4000Q & 6.7 & [33] \\
\hline 2 & Moulinet & France & 4.5 & $\begin{array}{l}\text { Temperate } \\
\text { oceanic }\end{array}$ & & & $\begin{array}{c}1 \text { June 2002-31 May } \\
2003\end{array}$ & 10 & 0.1 & 0.41 & $300 \mathrm{Q}$ & 9.8 & \\
\hline 3 & Incline Creek & $\begin{array}{l}\text { Nevada, } \\
\text { USA }\end{array}$ & 7.4 & Snow melt & $890-1270$ & $\begin{array}{c}\text { Sandy } \\
\text { decomposed } \\
\text { granite }\end{array}$ & 4 April-24 May 2000 & 15 & 0.2 & 0.34 & $100(\mathrm{Q}-0.2)$ & 0.5 & [34] \\
\hline 4 & Galabre & France & 20 & $\begin{array}{c}\text { Mediterranean } \\
\text { mountainous }\end{array}$ & $600-1200$ & $\begin{array}{l}\text { Limestone and } \\
\text { marls }\end{array}$ & $\begin{array}{c}\text { 3 October } \\
\text { 2007-23December } \\
2009\end{array}$ & 10 & 1 & 22 & $300 \mathrm{Q}$ & 2200 & [35] \\
\hline 5 & Owenabue & Ireland & 103 & $\begin{array}{l}\text { Temperate } \\
\text { oceanic }\end{array}$ & $\sim 1200$ & Mudstone and & $\begin{array}{c}15 \text { September 2009-15 } \\
\text { September } 2010\end{array}$ & 15 & 5 & 17 & $1.5 \mathrm{Q}$ & 170 & [16] \\
\hline 6 & Bandon & Ireland & 424 & $\begin{array}{l}\text { Temperate } \\
\text { oceanic }\end{array}$ & & & $\begin{array}{c}10 \text { February } 2010-9 \\
\text { February } 2011\end{array}$ & 15 & 10 & 110 & $0.1 \mathrm{Q}$ & 480 & \\
\hline 7 & Bès & France & 165 & $\begin{array}{c}\text { Mediterranean } \\
\text { mountainous }\end{array}$ & $600-1200$ & $\begin{array}{l}\text { Limestone and } \\
\text { marls }\end{array}$ & $\begin{array}{l}1 \text { April 2008-31 } \\
\text { December } 2009\end{array}$ & 10 & 10 & 143 & $100 \mathrm{Q}$ & 26,600 & [35] \\
\hline 8 & Ribera Salada & Spain & 114 & $\begin{array}{c}\text { Mediterranean } \\
\text { mountainous }\end{array}$ & 760 & $\begin{array}{l}\text { Limestone and } \\
\text { conglomerates }\end{array}$ & $\begin{array}{l}1 \text { November 2005-30 } \\
\text { October } 2008\end{array}$ & 5 & 1 & 5.85 & $\begin{array}{c}10 \mathrm{Q}^{0.5}+ \\
0.1 \mathrm{Q}^{4}\end{array}$ & 53.4 & [36] \\
\hline 9 & Isabena & Spain & 445 & $\begin{array}{c}\text { Mediterranean } \\
\text { mountainous }\end{array}$ & 770 & $\begin{array}{l}\text { Limestone, } \\
\text { marls and } \\
\text { clay-rocks }\end{array}$ & $\begin{array}{l}1 \text { November 2007-30 } \\
\text { September } 2012\end{array}$ & 15 & 10 & 68 & $0.02 Q^{3}+100$ & 100,100 & [37] \\
\hline 10 & Carapelle & $\begin{array}{l}\text { Southern } \\
\text { Italy }\end{array}$ & 506 & Mediterranean & $450-800$ & clayey-loamy-sandy & $\begin{array}{c}1 \text { January 2007-31 } \\
\text { December 2011 }\end{array}$ & 30 & 8 & 37 & $5 Q^{2}$ & 23,000 & {$[38]$} \\
\hline 11 & Hopland $^{+}$ & $\begin{array}{l}\text { California, } \\
\text { USA }\end{array}$ & 938 & Mediterranean & $1000-1200$ & $\begin{array}{l}\text { Sand-gravel and } \\
\text { silty materials }\end{array}$ & $\begin{array}{c}1 \text { October } 2010-31 \\
\text { December 2014 } \\
1 \text { October 2009-31 }\end{array}$ & 15 & 10 & 425 & $2 \mathrm{Q}$ & 26,560 & {$[31,32,39]$} \\
\hline 12 & Guerneville $^{+}$ & $\begin{array}{l}\text { California, } \\
\text { USA }\end{array}$ & 3465 & Mediterranean & $1000-1200$ & $\begin{array}{l}\text { Sand-gravel and } \\
\text { silty materials }\end{array}$ & $\begin{array}{l}\text { September 2010/ } 1 \\
\text { October 2012-31 } \\
\text { December 2014 }\end{array}$ & 15 & 20 & 890 & $0.5 \mathrm{Q}$ & 83,960 & \\
\hline 13 & Meuse & $\begin{array}{l}\text { Belgian-Dutch } \\
\text { border }\end{array}$ & 21,000 & European-continental & $1800-1000$ & $\begin{array}{l}\text { Limestone, } \\
\text { shales and } \\
\text { sandstone }\end{array}$ & $\begin{array}{c}1 \text { October } 1995-30 \\
\text { November } 2010\end{array}$ & 1440 & 280 & 1700 & $0.03 \mathrm{Q}$ & 187,800 & [40] \\
\hline
\end{tabular}

${ }^{+}$Data were obtained from a previous study [32] 
These catchments are classified into 5 categories according to their climatic characteristics or geographical regions: (i) temperate oceanic, (ii) snowmelt, (iii) Mediterranean mountainous, (iv) Mediterranean, and (v) European-continental (Table 1).

The temperate oceanic climate is represented by two catchments located in Northwestern France, Violettes and Moulinet, where the mean longitudinal channel slope is about $1.8 \%$ in both sites $[33,41]$. The land in this region is used extensively for dairy cattle farming, including pastures. Cattle disturbance has been associated with bank erosion and increased suspended sediment concentration in the stream [42]. Turbidity sensors were installed at the outlet of each catchment and $C$ was estimated from the relationship between turbidity and C [41]. The $Q$ and $C$ parameters were measured every $30 \mathrm{~s}$, and 10-min average values were reported. Similar climatic and land use conditions are found in the Owenabue and Bandon catchments in Southern Ireland, where $90 \%$ of the land is used for pasture and tillage [16]. The $Q$ and $C$ values of these two catchments were provided by Ireland's National Office of Public Works for $\mathrm{Q}$ and the Cork Institute of Technology for C.

Snowmelt- and glacial melt-dominated streams have periodic flow rates and corresponding fine sediment concentration fluctuations [29]. One of such streams was the Incline Creek in Nevada, which drains into Lake Tahoe, CA, USA. For this stream, $Q$ and $C$ were measured at 15 -min intervals between 4 April and 24 May 2000. This snowmelt-dominated catchment provides an extreme test of the model, given that there are only $24 \mathrm{~h}$ between flood events. The gauge elevation is $2100 \mathrm{~m}$ a.s.l., therefore, winter precipitation falls mainly in the form of snow. The flow regime of the United States Geological Survey (USGS) station (site number 103366993) shows daily cycles reflecting snowmelt conditions in spring. The $\mathrm{C}$ was continuously estimated from turbidity measurements, based on the turbidity-C relationship developed by Langlois et al. [34]. The earlier arrival of suspended sediment concentration peaks compared with peak water discharge shows clockwise hysteresis loops for almost all flood events.

The Mediterranean mountainous climate was assessed in four different catchments located in two different regions. Firstly, the two tributaries of the Bléone catchment, the Galabre and Bes rivers, located in the subalpine region of southeastern France, were evaluated. The climate of the catchment is characterized by a pronounced seasonality with the occurrence of frost in winter and high-intensity rainfall in summer. The peak water discharge during the spring season is affected by snowmelt in the Bès catchment where the median grain size of bed surface materials is $70 \mathrm{~mm}[35,43]$. The main types of land cover found are forests, scrubland, sparse vegetation, and grassland. Continuous $Q$ and $C$ values were monitored at two gauging stations located at the outlet. Depending on its magnitude, the $Q$ was regularly gauged with the salt $(\mathrm{NaCl})$ dilution method and a current flow meter. The concentration $\mathrm{C}$ was estimated from turbidity data based on the method developed by Navratil et al. [44].

The Ribera Salada stream, located in the southern Pyrenees, and the river Isábena (which presents frequent flooding that causes relatively high sediment transport rates) located in the southern central Pyrenees, are others representative of the Mediterranean mountainous climate. Mean annual precipitation at both catchments is around $800 \mathrm{~mm}$, being the monitoring period selected for the present study representative of the long-term hydrological regime. Predominant land uses are forest in headwaters and forest mixed with agriculture at the lowlands. Q and C (estimated from turbidity sensors by establishing rating curves between turbidity and C) were continuously measured at 15-min intervals, at the Inglabaga monitoring station (channel slope at around $1 \%$ ) in the case of the former [36,45], and at the Capella gauging station (channel slope at around $0.4 \%$ ) for the latter, and the median grain sizes of bed surface materials are $49.0 \mathrm{~mm}$ and $69.5 \mathrm{~mm}$ in the Ribera Salada and Isábena catchments, respectively [37,46].

Another different Mediterranean environment is that of the Carapelle catchment, located in the Puglia region of Southern Italy. It presents yearly precipitation that ranges from 450 to $800 \mathrm{~mm}$, and land use is mostly agricultural where the mean slope of main channel is $1.8 \%$ [38,47]. Continuous $Q$ and C values have been measured from 1 January 2007 to 31 December 2011 in this catchment, which is characterized by long periods with low flows and a prevalence of counter-clockwise hysteresis [48]. 
For this reason, a shorter period, between 3 March and 31 April 2009, was utilized for calibration in this study where 2009 was quite humid year (annual rainfall $786 \mathrm{~mm}$ ) [38,47].

The Hopland and Guerneville catchments, both located in the Russian River, California, CA, USA, analyzed in a previous study [32] were included in the catchment list; the climate in this region is also Mediterranean-type, with warmer, drier summers and cooler, wetter winters, where the median grain sizes of bed surface materials are $7.9 \mathrm{~mm}$ and $7.1 \mathrm{~mm}$ in the Hopland and Guerneville catchments, respectively.

Finally, the wet European-continental climate was considered with the inclusion of the Meuse River catchment, located at the Belgian-Dutch border, with a length of $935 \mathrm{~km}$ and a catchment area of $36,000 \mathrm{~km}^{2}$, where wet season is between October and April, and dry season is between May and September [40]. The main channel has steep slopes and land is dominantly used for both agriculture and forest [40]. Daily Q and C data reported over 15 years by the Dutch Institute for Inland Water Management and Waste Water Treatment (RIZA) are available from the upstream of the Eijsden gauging station, where the river length is approximately $700 \mathrm{~km}$ and the catchment area is $\sim 21,000 \mathrm{~km}^{2}$. Because the identification of model parameters requires sufficient resolution to discern the hysteresis of $\mathrm{C}$ to $\mathrm{Q}$ in rising and falling limbs during a flood event, daily data were applicable for model simulation in this relatively large catchment.

\subsection{Model Description}

The model applied in this study was developed by Park et al. [32]. The model estimates in-channel storage and re-suspension of fine sediment through three phases (Phase 1-3). In the model, it is considered that the effect of other catchment characteristics, such as channel morphology, on sediment dynamics is included through two parameters. This simplicity is one of the benefits for the application of this model. The model development process will not be described in detail in this study, but the main concepts are summarized.

\subsubsection{Fine Sediment Accumulation}

In Phase 1 , when $Q$ is less than the critical flow rate $\left(Q_{c}\right)$ to initiate sediment bed material mobilization, the fine sediments in the water column are accumulated in the sediment bed through hyporheic flow. The change of accumulated fine sediments mass during the time period from $t$ to $t+\Delta t$ is represented by Equation (1), which was derived by considering that the mass of fine sediments accumulated in the sediment bed is proportional to the fine sediment concentration in surface water, $\mathrm{C}(\mathrm{t})$.

$$
\Delta \mathrm{M}(\mathrm{t})=\alpha \mathrm{C}(\mathrm{t})\left[1-\frac{\mathrm{M}(\mathrm{t})}{\mathrm{M}_{\max }}\right] \Delta \mathrm{t} \quad \text { for } \mathrm{Q}<\mathrm{Q}_{\mathrm{c}}
$$

where $\mathrm{M}$ is the mass of fine sediments accumulated within the pore space of the sediment bed. The maximum value of $M, M_{\max }$, represents the sediment particle accumulation capacity of the sediment bed. The sediment particle removal parameter, $\alpha\left(\mathrm{L}^{3} / \mathrm{T}\right)$, represents the filtration and settling of fine sediment particles within the sediment bed.

\subsubsection{Fine Sediment Re-Suspension}

In Phase 2, during the rising flood with $\mathrm{dQ} / \mathrm{dt}>0$ and $\mathrm{Q}>\mathrm{Q}_{\mathrm{c}}$, fine sediments are released from the sediment bed into the water column, because the bed materials become fluidized when $Q$ exceeds $\mathrm{Q}_{c}$, initiating mobilization of the bed material.

An analysis of the data from Haschenburger [49] leads to the assumption that the erosion depth of the sediment bed during a flood event is an exponential function of the peak flow rate $\left(\mathrm{Q}_{\text {peak }}\right)$. From this approach, it is assumed that the maximum bed erosion occurs at the maximum flow rate $\left(Q_{\max }\right)$ during the observation period, when the release of all fine sediment particles within the sediment bed is expected. Thus $\mathrm{M}_{\max }$ is observed at $\mathrm{Q}_{\max }$ (Appendix A.1). 
In the model, the ratio of fine sediments mass released from the sediment bed, $\mathrm{M}_{\mathrm{f} \text {,model }}$, to the maximum possible mass of fine sediments in storage, $\mathrm{M}_{\max }$, is expressed as an exponential function of the ratio of $Q_{\text {peak }}$ to $Q_{\max }$. Thus, the mass of fine sediments released from the sediment bed by flood event $i$ is

$$
\mathrm{M}_{\mathrm{fi}, \text { model }}=\mathrm{M}_{\max } \exp \left[-\beta\left(1-\frac{\mathrm{Q}\left(\mathrm{t}_{\mathrm{p}, \mathrm{i}}\right)}{\mathrm{Q}_{\max }}\right)\right],
$$

where $t_{p, i}$ is time at $Q_{p e a k}$ of flood event $i$ and $\beta$ a dimensionless sediment bed erosion parameter.

The mass of fine sediments remaining in the pore space of the sediment bed immediately after flood event $i$ is estimated from the difference between the accumulated fine sediment mass in the sediment bed before flood event $i$ and the mass of fine sediments released from the sediment bed by flood event $i$, as

$$
\mathrm{M}\left(\mathrm{t}_{\mathrm{p}, \mathrm{i}}\right)=\mathrm{M}\left(\mathrm{t}_{\mathrm{s}, \mathrm{i}}\right)-\mathrm{M}_{\max } \exp \left[-\beta\left(1-\frac{\mathrm{Q}\left(\mathrm{t}_{\mathrm{p}, \mathrm{i}}\right)}{\mathrm{Q}_{\max }}\right)\right],
$$

where $M(t)$ is the fine sediment mass accumulated in the sediment bed at time $t$, and $t_{s, i}$ is the time at the beginning of flood event $i$. In the model simulation, $M\left(t_{p, i}\right)$ is restricted to be non- negative.

\subsubsection{Fine Sediment Accumulation during Flood Recession}

Finally, in Phase 3, in the falling limb with $\mathrm{dQ} / \mathrm{dt}<0$ and $\mathrm{Q}>\mathrm{Q}_{\mathrm{c}}$, fine sediments can be removed by filtration through hyporheic flow and stored within the pore space of the sediment bed. During flood recession, the available capacity for sediment storage is limited by partial fluidization of the sediment bed, which reduces the volume of porous media available for sediment accumulation (Appendix A.2). In the model, the available capacity for sediment storage in the sediment bed during the flood recession of a flood event, $\mathrm{M}_{\text {cap }}$, is represented as

$$
\mathrm{M}_{\text {cap }}[\mathrm{Q}(\mathrm{t})]=\mathrm{M}_{\max }\left\{1-\exp \left[-\beta\left(1-\frac{\mathrm{Q}(\mathrm{t})}{\mathrm{Q}_{\max }}\right)\right]\right\},
$$

The change of accumulated fine sediments mass during the flood recession period is estimated by substituting $\mathrm{M}_{\mathrm{cap}}[\mathrm{Q}(\mathrm{t})]$ for $\mathrm{M}_{\max }$ in Equation (1) as

$$
\Delta \mathrm{M}(\mathrm{t})=\alpha \mathrm{C}(\mathrm{t})\left\{1-\frac{\mathrm{M}(\mathrm{t})}{\mathrm{M}_{\text {cap }}[\mathrm{Q}(\mathrm{t})]}\right\} \Delta \mathrm{t} \quad \text { for } \mathrm{Q}>\mathrm{Q}_{\mathrm{c}} \text { and } \mathrm{dQ} / \mathrm{dt}<0,
$$

\subsubsection{Model Simulation}

In the model, it is assumed that $\mathrm{M}$ is set to $\mathrm{M}_{\max }$ as an initial condition of model simulation, and remains fixed at $\mathrm{M}_{\max }$ before the start of the first flood event. Then, flood event $\mathrm{i}$ with a flow rate exceeding $Q_{c}$ erodes the mass $M_{f i, m o d e l}$, which is estimated by Equation (2), into the water column. During the flow recession, $\mathrm{M}_{\text {cap }}$ is limited below $\mathrm{M}_{\max }$, and as the flow rate recedes, $\mathrm{M}_{\text {cap }}$ increases. In the case of another flood event occurring before the flow rate recedes below $Q_{c}$, additional sediment re-suspension occurs, which also can be estimated by Equation (2). In the case that the flow rate recedes below $Q_{c}$, sediment particles can accumulate in the pore space of the sediment bed up to the maximum capacity $\mathrm{M}_{\max }$, where the accumulation rate is limited by the available mass of fine sediments in the water column. The model estimates the mass of fine sediment storage and re-suspension during the repeated cycles of flood events.

\subsection{Determination of the Model Parameters}

The input parameters for the model simulation are $Q_{c}, M_{\max }, Q_{\max }$, and background suspended sediment concentration $\left(C_{b}\right)$. These parameters were determined for the 13 catchments using Equations (6)-(8) following Park et al. [32] as described below. 
Park et al. [31] observed the transition in the relationship between suspended sediment load $\left(Q_{s}\right)$ and $Q$, which occurs when the flow initiates mobilization of bed materials. The value of $Q$ at the transition corresponds to the $Q$ that initiates bed mobilization, defined as $Q_{c}$. The suspended sediments in the water column above the sediment bed are separated according to the source of the sediments as "background suspended sediments from the catchment $\left(\mathrm{C}_{b}\right)$ " and "fine sediments released from the sediment bed during the rising limb of a flood event", where $C_{b}$ is site-specific and represented by Equation (6):

$$
\mathrm{C}_{\mathrm{b}}(\mathrm{t})=\gamma \mathrm{Q}(\mathrm{t}),
$$

in which $C_{b}$ is expressed in $(\mathrm{mg} / \mathrm{L}), Q$ is expressed in $\left(\mathrm{m}^{3} / \mathrm{s}\right)$, and $\gamma$ is expressed in $\left(\mathrm{mg} \cdot \mathrm{s} / \mathrm{L} / \mathrm{m}^{3}\right)$.

The observed mass released from the sediment bed into the water column by a flood event $\left(\mathrm{M}_{\mathrm{f} \text {, obs }}\right)$

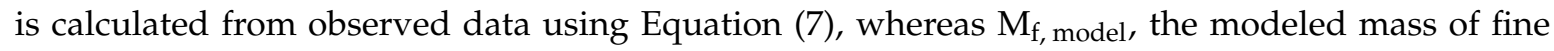
sediments released from the sediment bed into the water column by a flood event, is estimated by Equation (2):

$$
M_{f i, o b s}=\int_{t_{s, i}}^{t_{e, i}} Q(t)\left[C(t)-C_{b}(t)\right] d t,
$$

The lower limit of integration $t_{s, i}$ is the beginning of flood event $i$, which is either the first occurrence when $Q\left(t_{s}\right)>Q_{c}$ or when $d Q(t) / d t$ transitions from negative to positive, while $Q>Q_{c}$ during multiple high-flow events. The upper limit of integration $t_{e, i}$ represents the time of the end of flood $\mathrm{i}$, either when $\mathrm{Q}\left(\mathrm{t}_{\mathrm{e}, \mathrm{i}}\right)<\mathrm{Q}_{\mathrm{c}}$ or when $\mathrm{dQ} / \mathrm{dt}$ transitions from negative to positive. The maximum value of $\mathrm{M}_{\mathrm{f} \text {, obs }}$ during the model calibration period is defined as $\mathrm{M}_{\max }$ in the sediment bed, assuming that all fine sediments stored in the sediment bed are re-suspended during the maximum flood event when the highest peak flow rate $\left(\mathrm{Q}_{\max }\right)$ is observed.

\subsection{Model Evaluation}

Two parameters, $\alpha$ and $\beta$, were utilized for model calibration. The fine sediment filtration parameter, $\alpha$, represents the removal of fine sediments from the water column by filtration and settling of fine sediments within the pore space of the sediment bed of the catchment and the bed erosion parameter, $\beta$, represents the erosion of the sediment bed during a flood event. The optimal values of model parameters ( $\alpha$ and $\beta$ ) were determined by a reiterative trial and error process to minimize the root-mean-square error to data standard deviation ratio (RSR), using Equations (8)-(10).

The model performance was also evaluated based on values of the term $R$, which is defined as the ratio of the modeled sediment mass released to the observed sediment mass released. The model performance is considered satisfactory when RSR $<0.70$ [50] and when $\mathrm{R}$ approaches 1 when there is a total agreement between observed and predicted values.

$$
\mathrm{R}=\frac{\sum_{\mathrm{j}=1}^{\mathrm{n}} \mathrm{M}_{\mathrm{fj}, \text { model }}}{\sum_{\mathrm{j}=1}^{\mathrm{n}} \mathrm{M}_{\mathrm{fj}, \mathrm{obs}}},
$$

where $\mathrm{n}$ is the number of flood events in the entire simulation period.

$$
\mathrm{RSR}=\frac{\sqrt{\sum_{\mathrm{i}=1}^{\mathrm{n}}\left(\mathrm{M}_{\mathrm{fi}, \text { obs }}-\mathrm{M}_{\mathrm{fi}, \text { model }}\right)^{2}}}{\sqrt{\sum_{\mathrm{i}=1}^{\mathrm{n}}\left(\mathrm{M}_{\mathrm{fi}, \mathrm{obs}}-\overline{\mathrm{M}_{\mathrm{f}, \mathrm{obs}}}\right)^{2}}},
$$

where $\mathrm{n}$ is the number of flood events and the mean observed mass released for all flood events is

$$
\overline{\mathrm{M}_{\mathrm{f}, \mathrm{obs}}}=\frac{1}{\mathrm{n}} \sum_{\mathrm{i}=1}^{\mathrm{n}} \mathrm{M}_{\mathrm{fi}, \mathrm{obs}}
$$


The period of data available for model simulation varies for each catchment. For catchments with more than three years of observations, about two-thirds of the data were used for model calibration and the remaining data were used for validation, except for the Meuse River where 15 years of data were available. Due to the longer period of observations in the Meuse River, five years were used for model calibration, whereas data from the remaining 10 years were used for model validation, in order to test the applicability of the model in a longer period.

\section{Results}

\subsection{Model Parameters}

The model parameters (i.e., $\mathrm{Q}_{c}, \mathrm{C}_{\mathrm{b}}, \mathrm{M}_{\max }$, and $\mathrm{Q}_{\max }$ ) were determined from analysis of observed data in each of the 13 catchments (Figures S1 and S2 in Supplementary Materials) and are summarized in Table 1; a complete set of figures for all catchments is presented in Supplementary Materials, and in the next we present some observations on the data.

Slope breaks in the relationship between $Q_{s}$ to $Q$ were observed at flow rates of $5 \mathrm{~m}^{3} / \mathrm{s}$ for Owenabue and $10 \mathrm{~m}^{3} / \mathrm{s}$ for Bandon (Figure S1). The falling limb flow recessions asymptotically approached a linear relationship between $C$ and $Q$, which defined the assumed background suspended sediment concentration dependence on $\mathrm{Q}$ as $\mathrm{C}_{\mathrm{b}}(\mathrm{Q})=1.5 \mathrm{Q}$ for Owenabue and $\mathrm{C}_{\mathrm{b}}(\mathrm{Q})=0.1 \mathrm{Q}$ for Bandon (Figure 2).

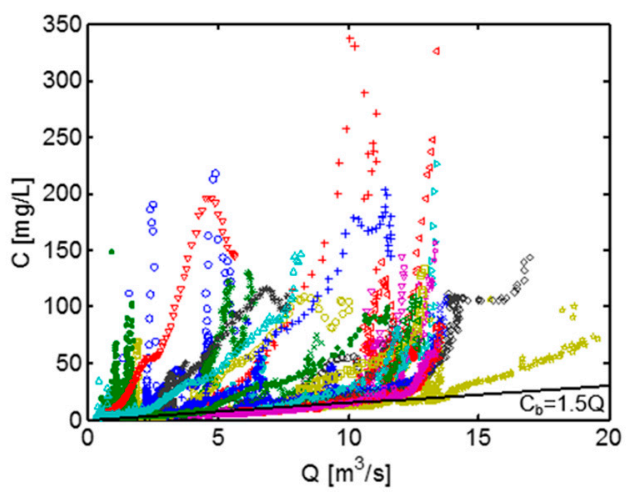

(a)

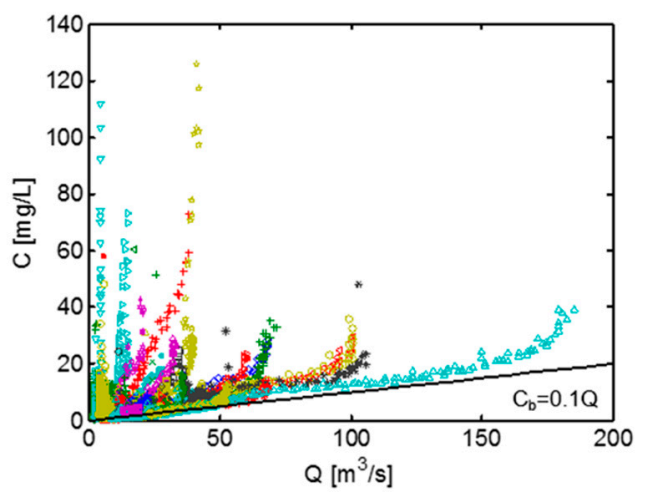

(b)

Figure 2. Fine sediment concentration data during falling limb recession of each flood event for Owenabue from 15 September 2009, to 15 September 2010 (a), and Bandon from 10 February 2010, to 9 February 2011 (b). The symbols with different colors and shapes represent different flood events.

Unlike in the other catchments, the range in $Q$ was rather small for Incline Creek; that is, 0.15 to $0.45 \mathrm{~m}^{3} / \mathrm{s}$. In addition, the flow rates above $0.28 \mathrm{~m}^{3} / \mathrm{s}$ are reported only within a resolution of $1 \mathrm{cfs}$ (cubic feet per second), thus $0.028 \mathrm{~m}^{3} / \mathrm{s}$, which was the minimum resolution of the flow rate measurement for this USGS gauging site, leading to limited resolution of the recession curve and vertically aligned data beyond flow rates of $0.28 \mathrm{~m}^{3} / \mathrm{s}$ (Figure $\mathrm{S} 1$ ).

The relationship of $Q_{s}$ to $Q$ for water discharge above $1 \mathrm{~m}^{3} / \mathrm{s}$ for the Ribera Salada showed noticeable expansion of vertical scatter. Thus, $Q_{c}$ was determined to be $1 \mathrm{~m}^{3} / \mathrm{s}$, which corresponds to previous observations [51]. In three catchments, Ribera Salada, Isabena, and Carapelle, considerable scatter was observed in the relationship between $Q_{s}$ and $Q$, and power laws show a reasonably good fit with the falling limb recession of flood events (Figure S2). Thus, power laws were utilized for the estimation of the background fine sediment concentrations (Table 1). The $Q_{c}$ values in two subalpine regions, Galabre and Bès, were determined to be $1 \mathrm{~m}^{3} / \mathrm{s}$ and $10 \mathrm{~m}^{3} / \mathrm{s}$, respectively (Figure S1).

The hysteresis analysis of sequential flood events provides better insight into model parameter determination. For example, much less hysteresis is observed during the second flood event of the two sequential events with similar peak flow rates between 9 and 10 August 2002, in Moulinet, France 
(Figure 3). This represents the depletion of stored suspended sediments by the preceding flood event and suggests that the suspended sediments were mostly supplied from the catchment during the second flood event. The observed mass of the fine sediments released from the sediment bed was 2.0 Mg for the first flood and $0.6 \mathrm{Mg}$ for the second flood. The background suspended sediment concentration relationship $C_{b}=300 Q$ for Moulinet shows consistency with the suspended sediment concentration during the recession of the two flood events (Figure 3). A similar pattern of fine sediment dynamics in sequential flood events was also observed in the examples of hysteresis analysis between $\mathrm{Q}$ and $\mathrm{C}$ in other catchments. For example, much less hysteresis was observed during the second flood event of the two sequential flood events at Owenabue between 5 and 10 December 2009, at Incline Creek between 4 and 6 May 2000 and at the largest catchment Meuse between 1 December 1999 and 26 January 2000 (Figure S3). The background suspended sediment concentration relationship also shows consistency with the suspended sediment concentration during the recession of the two flood events at each site.

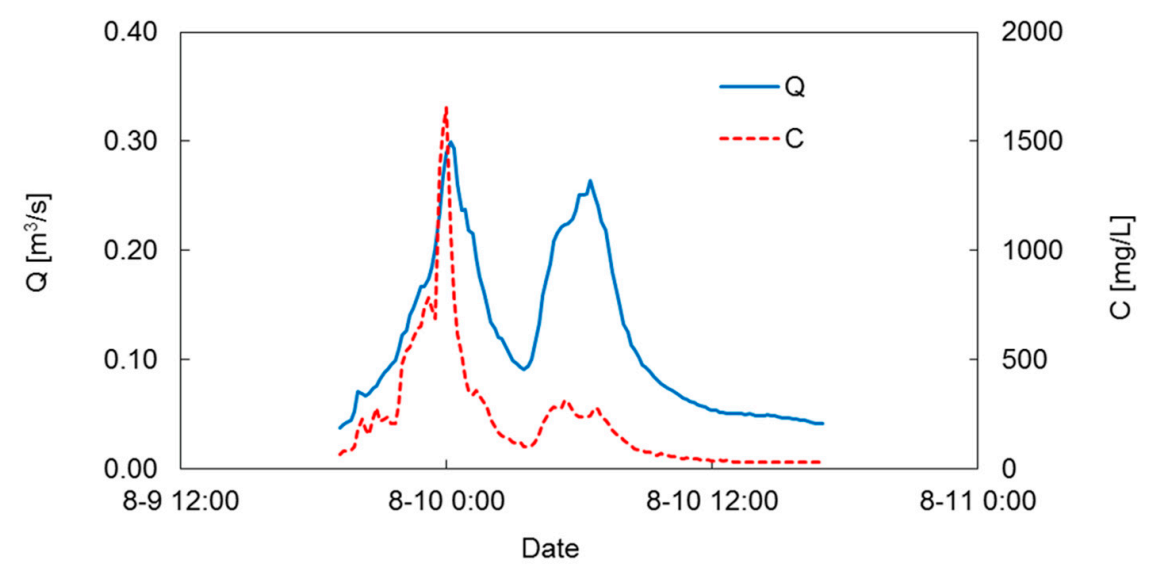

(a)

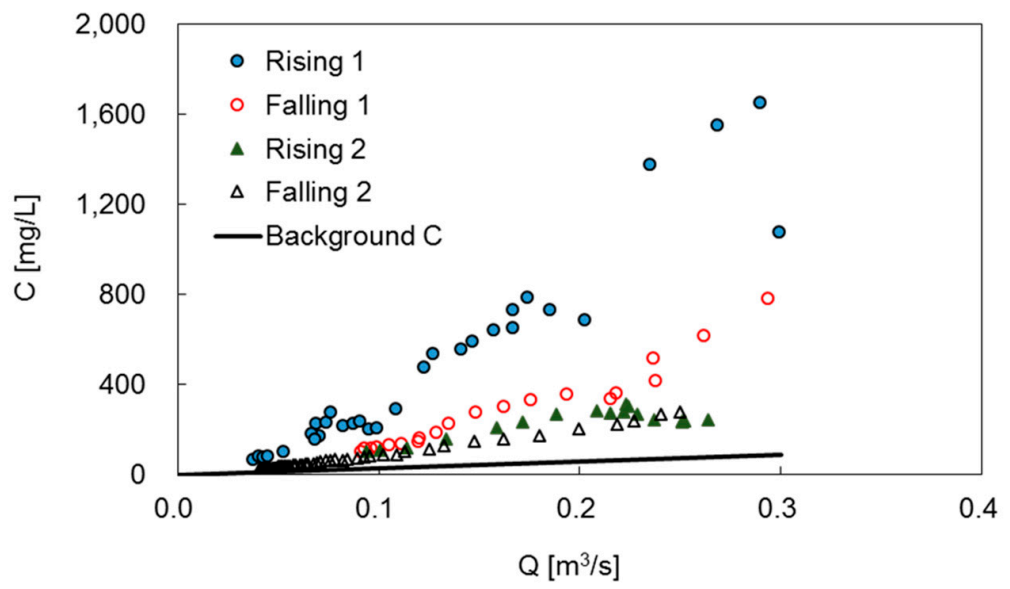

(b)

Figure 3. (a) Hydrograph (date format: month-day hour:min) and (b) hysteresis of sediment concentration (C) to suspended sediment load (Q) for sequential floods in Moulinet between 9 and 10 August 2002.

\subsection{Model Calibration}

Model calibration results are summarized in Table 2. The model was calibrated for each catchment to determine optimal model parameters ( $\alpha$ and $\beta$ ) that minimize RSR (Figure S4 in Supplementary Materials). Figure 4 shows examples of model calibrations for two catchments, Owenabue and Bandon in Ireland, where the RSR was 0.49 and 0.36 , respectively. The number of flood events in each catchment ranged from 22 to 79 during the calibration period. The filtration parameter, $\alpha$, ranged from 0.022 to $1650 \mathrm{~m}^{3} / \mathrm{s}$, whereas relative consistency was observed for the bed erosion parameter, $\beta$, ranging from 
2.4 to 5.3 (Figure S4 in Supplementary Materials). The model parameter sensitivity analysis shows that the model calibration stably converges to optimal values, and is more sensitive to change in $\alpha$ rather than $\beta$, in the two small catchments in France (Violettes and Moulinet), the snowmelt-dominated Incline Creek, and Carapelle (Figure S4). In the relatively larger catchments of Isabena, Guerneville, and Meuse, the model calibration also converges to optimal values, although it is more sensitive to change in $\beta$ rather than $\alpha$ (Figure S4 and Park et al. [32]). In the other six catchments, Galabre, Owenabue, Bandon, Bès, Ribera Salada, and Hopland, the model calibrations are less sensitive to the change of $\alpha$ than to that of $\beta$ when $\alpha$ is larger than the optimal value (Figure S4 and Park et al. [32]).

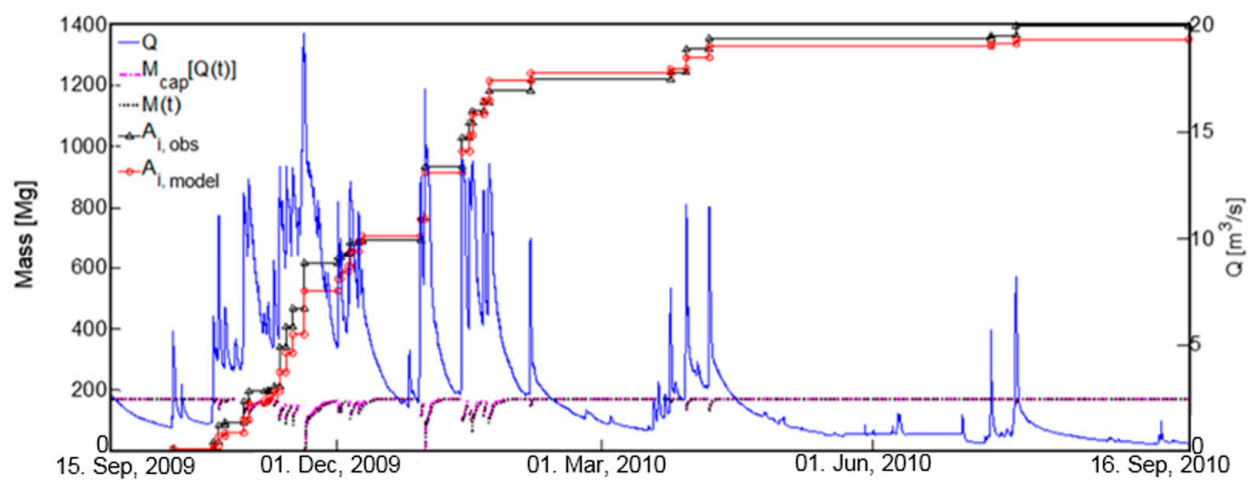

(a)

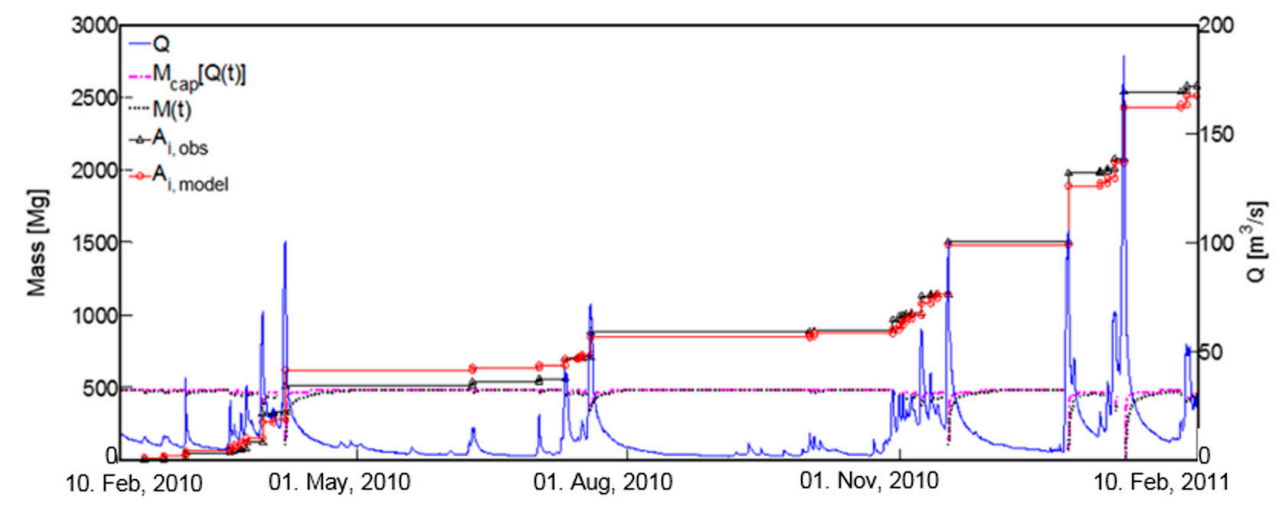

(b)

Figure 4. Model calibration output for (a) Owenabue from 15 September 2009 to 15 September 2010 and (b) Bandon from 10 February 2010 to 9 February 2011. The dashed magenta line represents the storage capacity of the sediment bed for fine sediments, $\mathrm{M}_{\text {cap }}[\mathrm{Q}(\mathrm{t})]$, and the dotted black line represents the mass of the fine sediments stored in the sediment bed, $\mathrm{M}(\mathrm{t})$. The black line with triangles represents the observed cumulative mass of fine sediments released from the sediment bed by the first i flood events $\left(\mathrm{A}_{\mathrm{i}, \mathrm{obs}}\right)$ and the red line with circles represents the modeled cumulative mass of sediments released for the first i flood events $\left(A_{i, \text { model }}\right)$.

The model-estimated cumulative mass of fine sediments released from the sediment bed shows a good fit to the observations for the 13 catchments (Table 2 and Figure S5). The average RSR value in these 13 catchments is 0.54 , ranging from 0.33 to 0.97 , where the largest RSR of 0.97 is observed in the Isabena catchment. The model also estimated an observation bias of less than $20 \%$ in 12 catchments, except for Violettes, where R was 1.23 (Table 2).

The mass of fine sediments released from channel beds, that is, the cumulative sum of $\mathrm{M}_{\mathrm{f} \text {, obs, }}$ ranged from $18 \%$ to $65 \%$ of the total suspended sediment load in the 13 catchments during the model calibration periods (Table 2), which is consistent with previous studies [52-54]. 
Table 2. Model calibration results.

\begin{tabular}{|c|c|c|c|c|c|c|c|c|c|c|}
\hline \multirow{2}{*}{ No } & \multirow{2}{*}{ Sites } & \multicolumn{2}{|c|}{$\begin{array}{c}\text { Optimal } \\
\text { Model } \\
\text { Parameter }\end{array}$} & \multicolumn{3}{|r|}{ Calibration } & \multirow{2}{*}{$\begin{array}{l}\text { Number of } \\
\text { Flood Events }\end{array}$} & \multicolumn{3}{|c|}{ Fine Sediment Mass } \\
\hline & & $\begin{array}{c}\alpha \\
\left(\mathrm{m}^{3} / \mathrm{s}\right)\end{array}$ & $\beta$ & RSR & $\mathbf{R}$ & Period & & $\begin{array}{l}\text { Released } \\
\text { from } \\
\text { Sediment } \\
\text { Bed (Mg) }\end{array}$ & $\begin{array}{c}\text { Total Mass } \\
\text { Transported during } \\
\text { Observation } \\
\text { Period }(\mathrm{Mg})\end{array}$ & $\begin{array}{c}\text { Released from } \\
\text { Sediment Bed as } \\
\text { Percent of } \\
\text { Total (\%) }\end{array}$ \\
\hline 1 & Violettes & 0.022 & 5.3 & 0.68 & 1.23 & 1 June 2002-31 May 2003 & 50 & 33 & 144 & 23 \\
\hline 2 & Moulinet & 0.160 & 4.5 & 0.72 & 1.08 & 1 July 2002-30 June 2003 & 61 & 61 & 116 & 52 \\
\hline 3 & Incline Creek & 0.25 & 5 & 0.73 & 0.94 & 4 April-24 May 2000 & 36 & 3.8 & 11.9 & 32 \\
\hline 4 & Galabre & 20 & 2.4 & 0.64 & 1.05 & 3 October 2007-23 December 2009 & 39 & 14,000 & 26,000 & 54 \\
\hline 5 & Owenabue & 300 & 4.7 & 0.49 & 0.97 & 15 September 2009-15 September 2010 & 32 & 1400 & 2500 & 56 \\
\hline 6 & Bandon & 800 & 4.0 & 0.36 & 0.97 & 10 February 2010-9 February 2011 & 34 & 2580 & 3990 & 65 \\
\hline 7 & Bès & 10 & 4.2 & 0.33 & 1.07 & 1 April 2008-31 December 2009 & 39 & 46,600 & 258,000 & 18 \\
\hline 8 & Ribera Salada & 10 & 4.4 & 0.48 & 1.10 & 1 November 2005-30 October 2007 & 47 & 150 & 510 & 29 \\
\hline 9 & Isabena & 10 & 3.9 & 0.97 & 0.93 & 1 November 2007-30 September 2010 & 79 & 623,000 & $1,063,000$ & 58 \\
\hline 10 & Carapelle & 20 & 3.6 & 0.48 & 0.92 & 3 March-23 April 2009 & 22 & 109,400 & 360,300 & 30 \\
\hline 11 & Hopland $^{+}$ & 1000 & 4.4 & 0.36 & 1.02 & 1 October 2010-30 September 2013 & 69 & 137,000 & 330,000 & 42 \\
\hline 12 & Guerneville $^{\dagger}$ & 1050 & 4.3 & 0.35 & 0.83 & $\begin{array}{l}1 \text { October 2009-31 September 2010/ } 1 \\
\text { October 2012-30 September } 2013\end{array}$ & $\begin{array}{c}25 \text { (18 in } 2010 \\
\text { water year, } 8 \text { in } \\
2013 \text { water year) }\end{array}$ & 422,000 & 908,000 & 46 \\
\hline 13 & Meuse & 1650 & 4.3 & 0.47 & 1.06 & 1 October 1995-30 September 2000 & 52 & $1,053,900$ & $1,675,600$ & 63 \\
\hline
\end{tabular}

${ }^{+}$Data were obtained from a previous study [32]. 


\subsection{Model Validation}

The model was applied to five catchments (Ribera Salada, Isabena, Hopland, Guerneville, and Meuse) where data for validation were available. For model validation, it was assumed that there were no observed suspended sediment data during the validation period. Thus, $C_{b}(t)$ was substituted for $\mathrm{C}(\mathrm{t})$ as model input for phases 1 and 3 . The number of flood events in the five catchments ranged from 10 to 101 during the validation period. The proportion of the cumulative mass of fine sediments released from the sediment bed during a flood event to total suspended load ranged from $44 \%$ to $66 \%$. The mass was not compared in Hopland, where $\mathrm{C}$ data were not continuous during the validation period [32]. The validation results for each catchment are summarized in Table 3. The average RSR and $R$ of the five catchments were 0.65 and 1.11, respectively. The model estimated the cumulative released mass of fine sediments well, with only $2 \%$ bias, for the Ribera Salada catchment (Figure $5 \mathrm{a}$ ). The largest RSR of 1.04 was observed in the Isabena catchment, where R was 1.61 (Figure 5b). For the Meuse River, the model showed a good fit with the observations for the 10-year validation period with $20 \%$ bias (Figure 5 c). Overall, the model bias in the five catchments ranged from $2 \%$ to $61 \%$ (Table 3 ).

\subsection{Model Parameter Dependence on Catchment Characteristics}

Figure 6a plots $\log \alpha$ against the $\log$ of the catchment area, showing that there is an increase in $\alpha$ with area for smaller catchments. For catchments with areas of approximately $100 \mathrm{~km}^{2}$ and larger, a limited dependence on the area is observed. Although no clear dependency of $\alpha$ on climatic condition was observed, it is notable that similar values of $\alpha$, from 10 to 20, were observed in five catchments, four (Galabre, Bès, Ribera Salada, Isabena) in Mediterranean mountainous and one (Carapelle) in Mediterranean climate, regardless of catchment area. These five catchments are located around the Mediterranean Sea with Mediterranean-type climate, where climate and bedrock show similarities (for instance, limestone is present in many areas), except for Carapelle (a clayey-loamy dominated watershed). Relatively larger values of $\alpha(>100)$ were observed for the five largest catchments (i.e., Owenabue, Bandon, Hopland, Guerneville, and Meuse). The catchment data that could be analyzed thus far are limited, but it is encouraging that the filtration parameter is reasonably consistent, with area dependency and with similarity between sites of similar catchment area, among a wide range of catchments. Unlike the filtration parameter $(\alpha)$, the bed erosion parameter $(\beta)$ values varied within a narrow range of 2.4 to 5.3 in the 13 catchments without notable dependency on catchment area or other environmental characteristics (Figure 6b). 
Table 3. Model validation results.

\begin{tabular}{|c|c|c|c|c|c|c|c|}
\hline \multirow[b]{2}{*}{ Sites } & \multicolumn{3}{|r|}{ Validation } & \multirow{2}{*}{$\begin{array}{l}\text { Number of } \\
\text { Flood } \\
\text { Events }\end{array}$} & \multicolumn{3}{|c|}{ Fine Sediment Mass } \\
\hline & RSR & $\mathbf{R}$ & Period & & $\begin{array}{c}\text { Released from } \\
\text { Sediment Bed } \\
(\mathrm{Mg})\end{array}$ & $\begin{array}{l}\text { Total Mass Transported } \\
\text { during the Observation } \\
\text { Period (Mg) }\end{array}$ & $\begin{array}{c}\text { Released from } \\
\text { Sediment Bed as } \\
\text { Percent of Total (\%) }\end{array}$ \\
\hline Ribera Salada & 0.71 & 0.98 & 1 November 2007-30 October 2008 & 52 & 410 & 930 & 44 \\
\hline Isabena & 1.04 & 1.61 & 1 October 2010-30 September 2012 & 42 & 188,500 & 285,000 & 66 \\
\hline Hopland ${ }^{+}$ & 0.35 & 1.22 & $\begin{array}{c}\text { Ten flood events between } 1 \text { October } \\
2013 \text {, and } 31 \text { December } 2014\end{array}$ & 10 & - & - & - \\
\hline Guerneville $^{+}$ & 0.54 & 0.56 & 1 October 2013-31 December 2014 & 14 & 224,000 & 366,000 & 61 \\
\hline Meuse & 0.62 & 1.20 & 1 October 2000-30 November 2010 & 101 & $1,668,000$ & $2,884,000$ & 58 \\
\hline
\end{tabular}

${ }^{\dagger}$ Data were obtained from the previous study [32] 


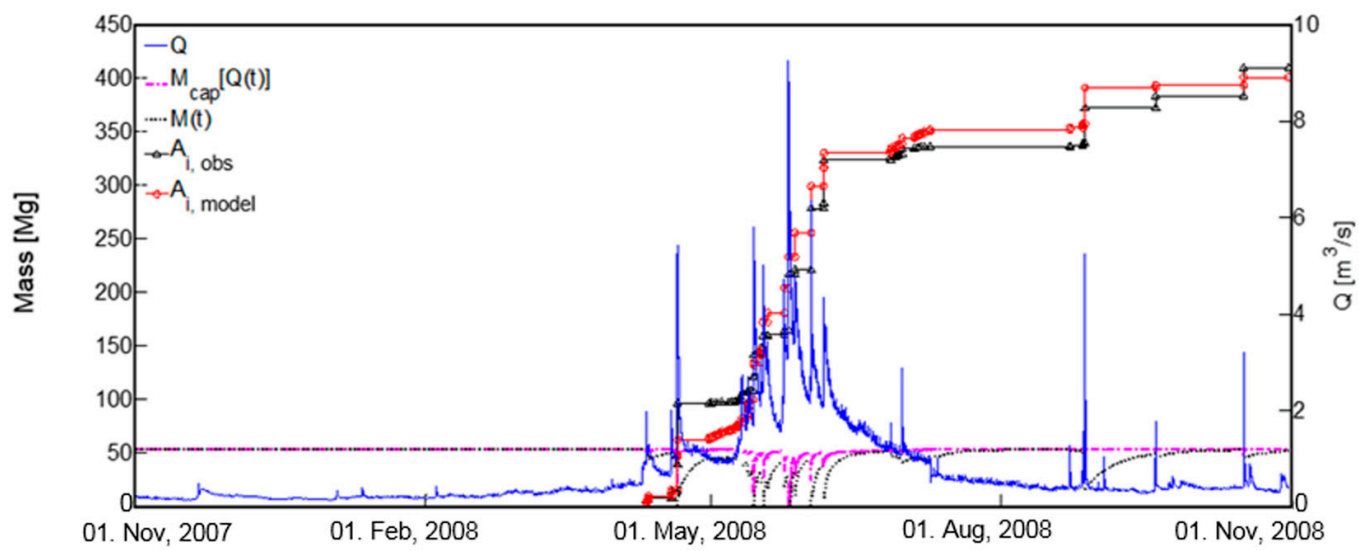

(a)

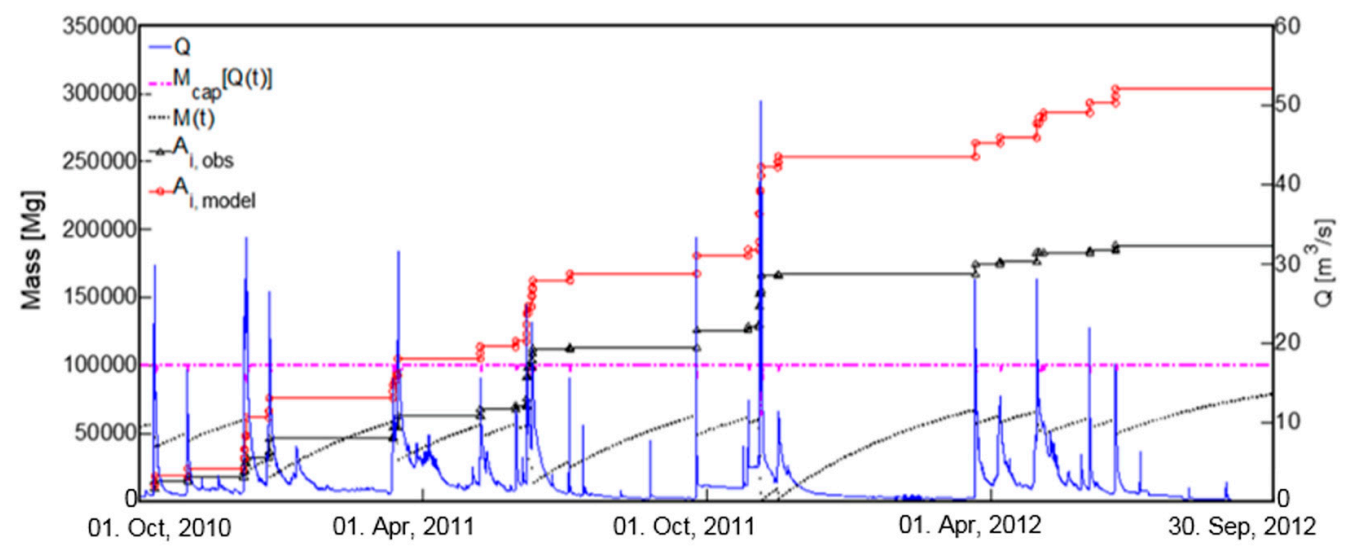

(b)

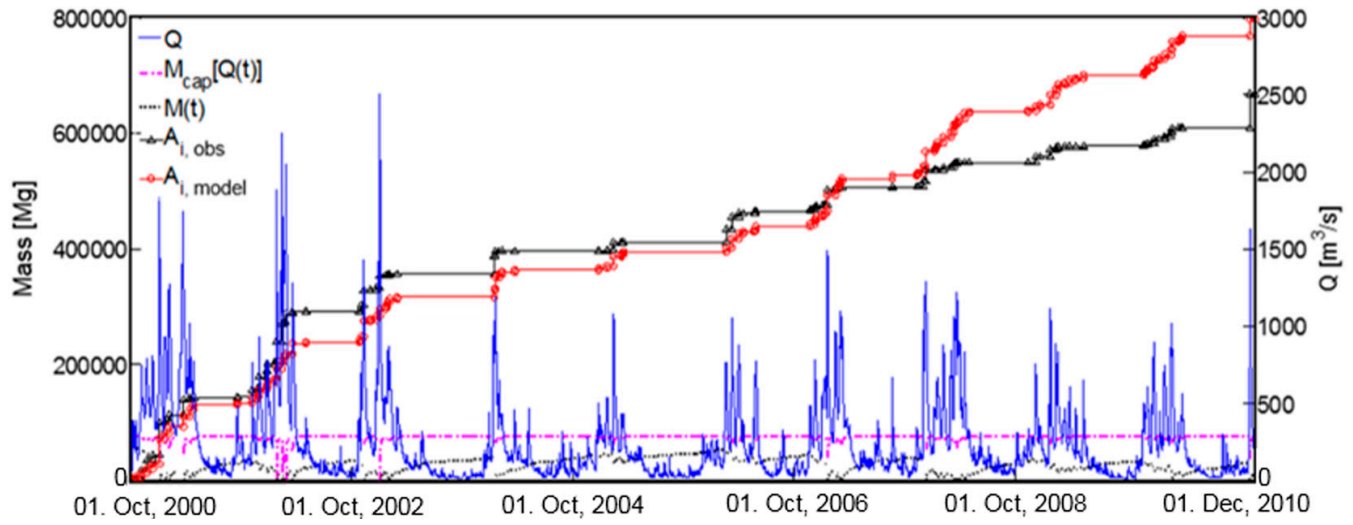

(c)

Figure 5. Model validation output for (a) the Ribera Salada from 1 November 2007 to 30 October 2008, (b) the Isabena from 1 October 2010 to 30 September 2012, and (c) the Meuse River from 1 October 2000 to 30 November 2010. The dashed magenta line represents the storage capacity of the sediment bed for fine sediments, $\mathrm{M}_{\mathrm{cap}}[\mathrm{Q}(\mathrm{t})]$, and the dotted black line represents the mass of fine sediments stored in the sediment bed, $M(t)$. The black line with triangles represents the observed cumulative mass of fine sediments released from the sediment bed by the first i flood events $\left(A_{i, o b s}\right)$ and the red line with circles represents the modeled cumulative mass of sediments released for the first i flood events $\left(A_{i, m o d e l}\right)$. 




$\square$ Violettes

$\diamond$ Moulinet

$\Delta$ Incline Creek

OGalabre

- Owenabue

$\triangle$ Bandon

$\times$ Bes

* Ribera Salada

+ Isabena

$\square$ Carapelle

OHopland

\&Guerneville

$\diamond$ Meuse

(a)

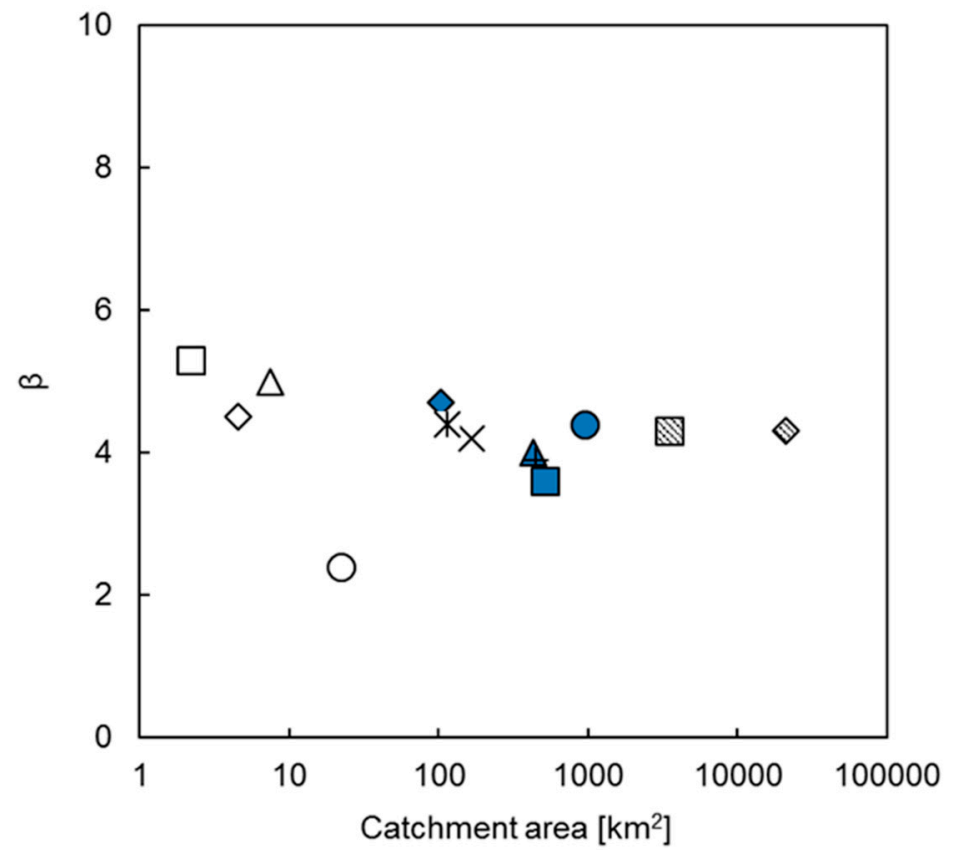

$\square$ Violettes

$\diamond$ Moulinet

$\Delta$ Incline Creek

OGalabre

$\diamond$ Owenabue

$\triangle$ Bandon

$\times$ Bes

* Ribera Salada

+ Isabena

$\square$ Carapelle

o Hopland

هGuerneville

$\diamond$ Meuse

(b)

Figure 6. Model parameter dependency on the catchment area. (a) the relationship between $\alpha$ and the catchment area and (b) the relationship between $\beta$ and the catchment area.

\section{Discussion}

The storage and re-suspension model developed by Park et al. [32] was applied to multiple catchments in contrasted climatic conditions with different catchment areas and other catchment characteristics (e.g., soil properties, and land use). Area dependency of the filtration parameter was observed, and it is notable that five catchments with Mediterranean-type climates show consistency in $\alpha$, with ranges from 10 to 20 regardless of catchment scale. Relatively larger values of $\alpha(>100)$ were observed in larger catchments (i.e., Owenabue, Bandon, Hopland, Guerneville, and Meuse) where 
climatic conditions and bed material compositions were more variable (Table 1). In the case of the bed erosion parameter, the values were within a narrow range. It is clear that both $\alpha$ and $\beta$ were affected by various environmental characteristics in each catchment. Understanding the effects of these various environmental characteristics on the model parameters, including the reason for the possible area dependency of $\alpha$ and relative consistency of $\alpha$ in the five catchments of Mediterranean-type climate, is suggested as a subject for future study.

The purpose of this study was to verify the general applicability of the storage and re-suspension model for catchments with various environmental characteristics and to understand the effect of environmental characteristics on the model performance. Therefore, providing specific values of model parameters for each catchment was out of the scope of this paper. Model calibration in 13 catchments shows a good fit with the real observations and thus verifies the possible applicability of the model, whereas there are certain areas where the applicability of the model can be improved in future studies, as described below.

(i) The first is to minimize uncertainties in determining the model input parameters $Q_{c}, Q_{\max }, C_{b}$, and $\mathrm{M}_{\max }$ for each catchment. Uncertainties in the determination of these model parameters can have various causes, such as limited periods of observation in the catchment and variability of sediment dynamics in the natural river system, which induce noticeable scatter of $Q_{s}$, even at the same water discharge. For example, as shown in the previous study [32], a larger peak flow rate $\left(1050 \mathrm{~m}^{3} / \mathrm{s}\right)$ than $\mathrm{Q}_{\max }\left(890 \mathrm{~m}^{3} / \mathrm{s}\right)$ was observed in Guerneville on 12 December 2014, during the validation period, which was not observed during the calibration period. The model-estimated mass of fine sediments released from the sediment bed was $72,600 \mathrm{Mg}$, which is only $~ 50 \%$ of the amount during the flood event [32].

In Carapelle, a $Q_{\max }$ of $37 \mathrm{~m}^{3} / \mathrm{s}$ and $M_{\max }$ of 23,000 Mg were observed on 5 March 2009, where the maximum flow rate during the model calibration period was $120 \mathrm{~m}^{3} / \mathrm{s}$, registered on 6 March 2009 . It is interesting that the flood with the largest mass of fine sediment release in Carapelle had a flow rate of only one third of the highest flow rates on record. As in Cantalice et al. [21], this could be explained by the fact that $C$ in the first flood is related to the re-suspension of deposited sediments, whereas it decreases in the subsequent events as considerable amount of sediment was re-suspended in the previous flood event. This suggests that high rates of fine sediment erosion are possible also at moderate flow rates.

An example of model parameter uncertainty can also be drawn from the model simulation result for the Isabena. There is relatively greater disagreement between the model estimation and observations of the fine sediment mass released from the sediment bed in the Isabena, where the RSR of the model calibration is 0.97 . This disagreement may be attributed to the wide range in observed suspended sediment concentrations during flood recession periods and baseflows, leading to considerable uncertainty in the assumed dependence of the background suspended sediment concentration on $\mathrm{Q}$. In the Isabena, $\mathrm{C}_{\mathrm{b}}$ was hardly discernable in the linear scale plot; thus, $\mathrm{C}_{\mathrm{b}}$ was determined from the log-log scale (Figure S2). The wide ranges of scatter in the relationship between $C$ and $Q$ in the two subalpine regions, Galabre and Bès, also cause uncertainty in the determination of $Q_{c}$ and $C_{b}$ in the two catchments. Unlike the Isabena, even with these constraints with respect to the application of the model, the calibrated model provides good representations of the fine sediment release during flood events, with $5 \%$ and $7 \%$ bias of the observation in the two catchments, Galabre and Bès, respectively.

Overall, model calibration and validation results in this study provide a good estimation of the observed sediment dynamics. However, consistent and longer-term observations will reduce possible uncertainties, including model parameter determination, and further improve model performance.

(ii) Secondly, there are possible issues that can cause considerable model bias, such as episodic events that may produce bank erosion. For example, the model reasonably estimated the observed mass of fine sediments released from the sediment bed in Violettes (Table 2). The observed mass of fine sediments released from the sediment bed $\left(\mathrm{M}_{\mathrm{f} \text {, obs }}\right)$ was less than $1 \mathrm{Mg}$ when $\mathrm{Q}$ was less than $0.1 \mathrm{~m}^{3} / \mathrm{s}$, 
except for the two flood events on 16 and 27 October 2002. The model-estimated mass of fine sediments released from the sediment bed $\left(\mathrm{M}_{\mathrm{f}}\right.$, model $)$ was less than $1 \mathrm{Mg}$ for all flood events including the two events specified above, while $\mathrm{M}_{\mathrm{f} \text {, obs }}$ was $3.5 \mathrm{Mg}$ and $2.1 \mathrm{Mg}$, where the $\mathrm{Q}$ of the two flood events on 16 and 27 October was $0.09 \mathrm{~m}^{3} / \mathrm{s}$ and $0.06 \mathrm{~m}^{3} / \mathrm{s}$, respectively. Thus, a considerable underestimation of $\mathrm{M}_{\mathrm{f} \text {, obs }}$ was observed for these two flood events. This underestimation by the model may be related to the additional supply of sediment by episodic events, such as bank erosion, associated with cattle trampling in riparian pastures from March to October [33,42].

The two model parameters in this study, $\alpha$ and $\beta$, successfully accounted for all variability despite contrasting environmental conditions, whereas episodic events may be considered little and may increase the uncertainty of the numerical model as it was assumed that the mass of fine sediment re-suspended from the sediment bed is proportional to the bed erosion depth which is considered as an exponential function of bed shear stress. Thus, better insights into the characteristics and episodic events of each catchment would provide a better understanding of the possible reasons for the model bias and thus clues for improving the model in future studies.

Various natural characteristics can affect fine sediment dynamics, and thus should be considered for the development of sediment dynamics models for rivers. For example, in catchments with low geomorphic activity, it is possible to obtain statistically significant multivariate models to predict suspended sediment concentrations [36]. However, in catchments with greater sedimentary activity, the results of these models fail to be significant through all the time, which indicates that sediment supply and the role of the riverbed acting as a sediment source or sink play fundamental roles [55]. Riverbed sediment clogging by cohesive sediment $(<63 \mu \mathrm{m})$ is also one of factors that have possible effect on sediment transport processes and it can be considered that in sites with sandy or sand-gravel such as the Incline Creek, the Hopland and the Guerneville, the bed material is not dominantly cohesive while the sediment is cohesive in sites with clay or silty bed material dominated such as the Violettes, the Moulinet, and the Isábena. The limitation of available information for the detailed characteristics and conditions of field sites limits the practical applicability of sediment model in many cases. Including more parameters would improve model performance but would also increase model complexity, and would require more effort for data observation and thus reduce the practical applicability of the model [32,56]. The model developed in this study includes only two model parameters, $\alpha$ and $\beta$, but shows good ability for estimating fine sediment storage mass in 13 catchments with various environmental characteristics, which is an obvious benefit of this model.

\section{Conclusions}

The general applicability of a storage and re-suspension model was tested in this study. The model was applied to 13 catchments with different climatic conditions (e.g., precipitation and hydrological conditions) and catchment area. The initial model parameters, $Q_{c}, Q_{\max }, C_{b}$, and $M_{\max }$, were determined from the observed data. The observed cumulative mass of fine sediments released from the bed in relation to the total suspended load during the model calibration period ranges from 18 to $65 \%$.

The model performance was evaluated using the statistical parameters RSR and R. The optimal model simulation parameters, $\alpha$ and $\beta$, were determined to be values that minimize the RSR based on trial and error. The RSR of the model calibration ranges from 0.33 to 0.97 , with an average value of 0.54 , and the $\mathrm{R}$ value ranges from 0.83 to 1.23 , with an average of 1.01 . The value of the filtration parameter, $\alpha$, ranges from 0.022 to $1650 \mathrm{~m}^{3} / \mathrm{s}$; a clear area dependency was observed up to an approximate catchment area of less than $100 \mathrm{~km}^{2}$. The bed erosion parameter, $\beta$, was set within a narrower range than $\alpha$, between 2.4 and 5.3 .

It is also noticeable that relatively small values of $\alpha$ from 10 to 20 were observed in five catchments located around the Mediterranean Sea with similar climate, while larger values of $\alpha(>100)$ were observed in five catchments with largest area.

Overall, the model estimated the mass of fine sediments released from the sediment bed in the 13 catchments within $\sim 23 \%$ bias. 
Supplementary Materials: The following are available online at http://www.mdpi.com/2073-4441/11/5/878/s1, Figure S1: $Q$ vs $Q_{s}$, Figure S2: Background line, Figure S3: Hysteresis analysis, Figure S4: Sensitivity analysis, Figure S5: Model calibration, Table S1: Study sites.

Author Contributions: Conceptualization: J.P.; Methodology: J.P.; Software: J.P.; Validation: J.P., R.J.B., F.B., M.E., F.G., J.R.H., O.N., J.A.L.-T., D.V.; Formal analysis: J.P., R.J.B., F.B., M.E., F.G., J.R.H., O.N., J.A.L.-T., D.V.; Investigation: J.P., R.J.B., F.B., M.E., F.G., J.R.H., O.N., J.A.L.-T., D.V.; Resources: J.P.; R.J.B., F.B., M.E., F.G., J.R.H., O.N., J.A.L.-T., D.V.; Data curation: J.P., R.J.B., F.B., M.E., F.G., J.R.H., O.N., J.A.L.-T., D.V.; Writing-original draft preparation: J.P.; Writing-review and editing: J.P., R.J.B., F.B., M.E., F.G., J.R.H., O.N., J.A.L.-T., D.V.; Visualization: J.P.; Supervision: J.P.; Project administration: J.P.; Funding acquisition: R.J.B., F.B., M.E., F.G., J.R.H., O.N., J.A.L.-T., D.V.

Funding: J. A. López-Tarazón is in receipt of a Vicenç Mut postdoctoral fellowship (CAIB PD/038/2016), while Damià Vericat is a a Serra Húnter Fellow at the University of Lleida. Authors acknowledge the support from the Economy and Knowledge Department of the Catalan Government through the Consolidated Research Group 2017 SGR 459 Fluvial Dynamics Research Group (RIUS). The data in Galabre and Bès were collected during the STREAMS (Sediment TRansport and Erosion Across Mountains) project, funded by the French National Research Agency (ANR/ BLAN06-1_13915).

Acknowledgments: This study applied a filtration and bed erosion model developed from the analysis of the United States Geological Survey field monitoring data, which was easily accessed from "California datacube" developed by the UC Berkeley Water Center in collaboration with the Lawrence Berkeley National Laboratory and Microsoft Research. Great thanks to Dr. Jacques L. Langlois for kindly provided data in Incline Creek, also thanks to Professor Hans Middelkoop at Utrecht University, the Netherlands, for kindly provided link to the flow and suspended sediment data for Meuse River.

Conflicts of Interest: The authors declare no conflict of interest. The funders had no role in the design of the study; in the collection, analyses, or interpretation of data; in the writing of the manuscript, or in the decision to publish the results.

\section{Abbreviations}

M mass

L length

$\mathrm{T}$ time

$\mathrm{Mg}$ megagram (equal to $1000 \mathrm{~km}$ )

$\mathrm{Q}\left(\mathrm{L}^{3} / \mathrm{T}\right) \quad$ water discharge

$\mathrm{Q}_{\mathrm{s}}(\mathrm{M} / \mathrm{T}) \quad$ fine sediment loading rate

$\mathrm{Q}_{\mathrm{c}}\left(\mathrm{L}^{3} / \mathrm{T}\right) \quad$ critical flow rate required to initiate the mobilization of sediment bed material

$\mathrm{Q}_{\text {peak }}\left(\mathrm{L}^{3} / \mathrm{T}\right) \quad$ peak flow rate of a flood event

$\mathrm{Q}_{\max }\left(\mathrm{L}^{3} / \mathrm{T}\right) \quad$ maximum recorded flow rate during the observation period

$\mathrm{C}\left(\mathrm{M} / \mathrm{L}^{3}\right) \quad$ concentration of fine sediments within the water column

$\mathrm{C}_{\mathrm{b}}\left(\mathrm{M} / \mathrm{L}^{3}\right) \quad$ background suspended sediment concentration from the catchment

$\mathrm{M}(\mathrm{M}) \quad$ mass of fine sediments accumulated within the pore space of the sediment bed

$\mathrm{M}_{\max }(\mathrm{M}) \quad$ maximum mass of fine sediments accumulated within the pore space of the sediment bed, representing the capacity of the sediment bed for fine sediments accumulation

$\mathrm{M}_{\mathrm{f}, \mathrm{obs}}(\mathrm{M})$ Observed mass of fine sediments released from the sediment bed into the water column

$\mathrm{M}_{\mathrm{f} \text {,model }}(\mathrm{M})$

$\mathrm{M}_{\text {cap }}(\mathrm{M})$ model-estimated mass of fine sediments released from the sediment bed into the water column capacity for fine sediment storage in the sediment bed

$\mathrm{A}_{\mathrm{i}, \mathrm{obs}}(\mathrm{M})$ observed cumulative mass of fine sediments released in the first i flood events of the season

$\mathrm{A}_{\mathrm{i}, \mathrm{model}}(\mathrm{M})$ model-estimated cumulative mass of fine sediments released in the first $\mathrm{i}$ flood events of the season

$\alpha\left(\mathrm{L}^{3} / \mathrm{T}\right) \quad$ sediment removal parameter representing filtration and settling of fine sediments within the sediment bed of the catchment

$\beta \quad$ dimensionless sediment bed erosion parameter

$t_{s, i}(T) \quad$ time at the start of a flood event $i$

$t_{p, i}(T) \quad$ time at the peak flow rate of a flood event $i$ 


\section{Appendix A. Details of Model Description}

Appendix A.1. Fine Sediment Re-Suspension

An analysis of the data from Haschenburger [49] leads to an assumption that the average depth of bed erosion was an exponential function of bed shear stress as

$$
\text { bed erosion depth at } Q_{\text {peak }} \propto \exp \left(\beta^{\prime} Q_{\text {peak }}\right),
$$

where $\beta^{\prime}$ is a bed erosion parameter.

From this approach, it is assumed that the maximum bed erosion depth occurs at $\mathrm{Q}_{\max }$ during the observation period as

$$
\text { maximum bed erosion depth at } \mathrm{Q}_{\max } \propto \exp \left(\beta^{\prime} \mathrm{Q}_{\max }\right) \text {, }
$$

The mass of fine sediments released from the sediment bed by a flood with $Q_{\text {peak }}$ is assumed to be proportional to the bed erosion depth and thus, $M_{\max }$ would be expected at $Q_{\max }$. The ratio of $\mathrm{M}_{\mathrm{f} \text {,model, }}$, to $\mathrm{M}_{\max }$ is

$$
\frac{\mathrm{M}_{\mathrm{f} \text {,model }}}{\mathrm{M}_{\max }}=\exp \left[\beta^{\prime} \mathrm{Q}_{\text {peak }}-\beta^{\prime} \mathrm{Q}_{\max }\right]=\exp \left[-\beta\left(1-\frac{\mathrm{Q}_{\text {peak }}}{\mathrm{Q}_{\max }}\right)\right],
$$

where $\beta$, a dimensionless sediment bed erosion parameter, is defined as $\beta^{\prime} Q_{\max }$.

Thus, the mass of fine sediments released form the sediment bed by flood event $i$ is

$$
\mathrm{M}_{\mathrm{fi}, \operatorname{model}}=\mathrm{M}_{\max } \exp \left[-\beta\left(1-\frac{\mathrm{Q}\left(\mathrm{t}_{\mathrm{p}, \mathrm{i}}\right)}{\mathrm{Q}_{\max }}\right)\right],
$$

where $t_{p, i}$ is time at $Q_{p e a k}$ of flood event $i$.

\section{Appendix A.2. Fine Sediment Accumulation during Flood Recession}

In this study, it is assumed that partial bed fluidization or erosion during falling limb of a flood event reduces the volume of porous media available for particle accumulation. For flood recession period with flow rate $Q(t)$, Equations (A1) and (A2) are modified using the substitution $\beta=\beta^{\prime} Q_{\max }$ and applied to the model as

$$
\begin{aligned}
& \text { bed erosion depth at } \mathrm{Q}(\mathrm{t}) \propto \exp \left[\beta \frac{\mathrm{Q}(\mathrm{t})}{\mathrm{Q}_{\max }}\right], \\
& \text { maximum bed erosion depth at } \mathrm{Q}_{\max } \propto \exp [\beta],
\end{aligned}
$$

The available capacity for fine sediment storage is estimated by subtracting the bed erosion depth during flow recession at a flow rate $Q(t)$ from the maximum bed erosion depth. Thus in the model, the available capacity for fine sediment storage in the sediment bed is represented during the falling limb of a flood event by

$$
\begin{gathered}
\frac{\mathrm{M}_{\text {cap }}[\mathrm{Q}(\mathrm{t})]}{\mathrm{M}_{\max }}=\frac{\exp [\beta]-\exp \left[\beta \frac{\mathrm{Q}(\mathrm{t})}{\mathrm{Q}_{\max }}\right]}{\exp [\beta]}=1-\exp \left[-\beta\left(1-\frac{\mathrm{Q}(\mathrm{t})}{\mathrm{Q}_{\max }}\right)\right], \\
\mathrm{M}_{\text {cap }}[\mathrm{Q}(\mathrm{t})]=\mathrm{M}_{\max }\left\{1-\exp \left[-\beta\left(1-\frac{\mathrm{Q}(\mathrm{t})}{\mathrm{Q}_{\max }}\right)\right]\right\},
\end{gathered}
$$




\section{References}

1. Droppo, I.G.; Liss, S.N.; Williams, D.; Nelson, T.; Jaskot, C.; Trapp, B. Dynamic existence of waterborne pathogens within river sediment compartments. Implications for water quality regulatory affairs. Environ. Sci. Technol. 2009, 43, 1737-1743. [CrossRef] [PubMed]

2. Søndergaard, M.; Jensen, J.P.; Jeppesen, E. Role of sediment and internal loading of phosphorus in shallow lakes. Hydrobiologia 2003, 506, 135-145. [CrossRef]

3. Singer, M.B.; Aalto, R.; James, L.A.; Kilham, N.E.; Higson, J.L.; Ghoshal, S. Enduring legacy of a toxic fan via episodic redistribution of California gold mining debris. Proc. Natl. Acad. Sci. USA 2013, 110, 18436-18441. [CrossRef]

4. Herrero, A.; Vila, J.; Eljarrat, E.; Ginebreda, A.; Sabater, S.; Batalla, R.J.; Barceló, D. Transport of sediment borne contaminants in a Mediterranean river during a high flow event. Sci. Total Environ. 2018, 633, 1392-1402. [CrossRef] [PubMed]

5. Quesada, S.; Tena, A.; Guillén, D.; Ginebreda, A.; Vericat, D.; Martínez, E.; Navarro-Ortega, A.; Batalla, R.J.; Barceló, D. Dynamics of suspended sediment borne persistent organic pollutants in a large regulated Mediterranean river (Ebro, NE Spain). Sci. Total Environ. 2014, 473, 381-390. [CrossRef] [PubMed]

6. Suttle, K.B.; Power, M.E.; Levine, J.M.; McNeely, C. How fine sediment in riverbeds impairs growth and survival of juvenile salmonids. Ecol. Appl. 2004, 14, 969-974. [CrossRef]

7. Béjar, M.; Gibbins, C.; Vericat, D.; Batalla, R.J. Effects of suspended sediment transport on invertebrate drift. River Res. Appl. 2017, 33, 1655-1666. [CrossRef]

8. Buendia, C.; Gibbins, C.N.; Vericat, D.; Batalla, R.J.; Douglas, A. Detecting the structural and functional impacts of fine sediment on stream invertebrates. Ecol. Indic. 2013, 25, 184-196. [CrossRef]

9. Buendia, C.; Gibbins, C.N.; Vericat, D.; Batalla, R.J. Effects of flow and fine sediment dynamics on the turnover of stream invertebrate assemblages. Ecohydrology 2014, 7, 1105-1123. [CrossRef]

10. Pelletier, J.D. A spatially distributed model for the long-term suspended sediment discharge and delivery ratio of drainage basins. J. Geophys. Res. 2012, 117, F2. [CrossRef]

11. Warrick, J.A.; Mertes, L.A.K. Sediment yield from the tectonically active semiarid Western Transverse Ranges of California. Geol. Soc. Am. Bull. 2009, 121, 1054-1070. [CrossRef]

12. Syvitski, J.P.; Morehead, M.D.; Bahr, D.B.; Mulder, T. Estimating fluvial sediment transport: The rating parameters. Water Resour. Res. 2000, 36, 2747-2760. [CrossRef]

13. Gao, P.; Nearing, M.A.; Commons, M. Suspended sediment transport at the instantaneous and event time scales in semiarid watersheds of southeastern Arizona, USA. Water Resour. Res. 2013, 49, 6857-6870. [CrossRef]

14. Warrick, J.A.; Madej, M.A.; Goni, M.A.; Wheatcroft, R.A. Trends in the suspended-sediment yields of coastal rivers of northern California, 1955-2010. J. Hydrol. 2013, 489, 108-123. [CrossRef]

15. Alexandrov, Y.; Laronne, J.B.; Reid, I. Intra-event and inter-seasonal behaviour of suspended sediment in flash floods of the semi-arid northern Negev, Israel. Geomorphology 2007, 85, 85-97. [CrossRef]

16. Harrington, S.T.; Harrington, J.R. An assessment of the suspended sediment rating curve approach for load estimation on the Rivers Bandon and Owenabue, Ireland. Geomorphology 2013, 185, 27-38. [CrossRef]

17. Klein, M. Anti clockwise hysteresis in suspended sediment concentration during individual storms: Holbeck catchment, Yorkshire England. Catena 1984, 11, 251-257. [CrossRef]

18. Carson, M.A.; Taylor, C.H.; Grey, B.J. Sediment production in a small Appalachian watershed during spring runoff: the Eaton Basin, 1970-1972. Can. J. Earth Sci. 1973, 10, 1707-1734. [CrossRef]

19. Williams, G.P. Sediment concentration versus water discharge during single hydrologic events in rivers. J. Hydrol. 1989, 111, 89-106. [CrossRef]

20. Harvey, J.W.; Drummond, J.D.; Martin, R.L.; McPhillips, L.E.; Packman, A.I.; Jerolmack, D.J.; Stonedahl, S.H.; Aubeneau, A.F.; Sawyer, A.H.; Larsen, L.G.; et al. Hydrogeomorphology of the hyporheic zone: Stream solute and fine particle interactions with a dynamic streambed. J. Geophys. Res. 2012, 117, G00N11. [CrossRef]

21. Cantalice, J.R.B.; Cunha, M.; Stosic, B.D.; Piscoya, V.C.; Guerra, S.M.S.; Singh, V.P. Relationship between bedload and suspended sediment in the sand-bed Exu River, in the semi-arid region of Brazil. Hydrol. Sci. J. 2013, 58, 1789-1802. [CrossRef]

22. Piqué, G.; López-Tarazón, J.A.; Batalla, R.J. Variability of in-channel sediment storage in a river draining highly erodible areas (the Isábena, Ebro Basin). J. Soil. Sediment. 2014, 14, 2031-2044. [CrossRef] 
23. Yang, C.C.; Lee, K.T. Analysis of flow-sediment rating curve hysteresis based on flow and sediment travel time estimations. Int. J. Sediment Res. 2018, 33, 171-182. [CrossRef]

24. Juez, C.; Hassan, M.A.; Franca, M.J. The origin of fine sediment determines the observations of suspended sediment fluxes under unsteady flow conditions. Water Resour. Res. 2018, 54, 5654-5669. [CrossRef]

25. Walling, D.E. The sediment delivery problem. J. Hydrol. 1983, 65, 209-237. [CrossRef]

26. Negev, M. Analysis of Data on Suspended Sediment Discharge in Several Streams in Israel; Hydrological Paper No. 12; Israel Hydrological Service: Jerusalem, Israel, 1969; pp. 8-17.

27. Alexandrov, Y.; Cohen, H.; Laronne, J.B.; Reid, I. Suspended sediment load, bed load, and dissolved load yields from a semiarid drainage basin: A 15-year study. Water Resour. Res. 2009, 45, W08408. [CrossRef]

28. Brasington, J.; Richards, K. Turbidity and suspended sediment dynamics in small catchments in the Nepal Middle Hills. Hydrol. Process. 2000, 14, 2559-2574. [CrossRef]

29. Stubblefield, A.P.; Reuter, J.E.; Goldman, C.R. Sediment budget for subalpine watersheds, Lake Tahoe, California, USA. Catena 2009, 76, 163-172. [CrossRef]

30. Achite, M.; Ouillon, S. Suspended sediment transport in a semiarid watershed, Wadi Abd, Algeria (1973-1995). J. Hydrol. 2007, 343, 187-202. [CrossRef]

31. Hunt, J.R. Coupling fine particle and bedload transport in gravel-bedded streams. J. Hydrol. 2017, 552, 532-543.

32. Park, J.; Hunt, J.R. Modeling fine particle dynamics in gravel-bedded streams: Storage and re-suspension of fine particles. Sci. Total Environ. 2018, 634, 1042-1053. [CrossRef]

33. Lefrançois, J.; Grimaldi, C.; Gascuel-Odoux, C.; Gilliet, N. Suspended sediment and discharge relationships to identify bank degradation as a main sediment source on small agricultural catchments. Hydrol. Process. 2007, 21, 2923-2933. [CrossRef]

34. Langlois, J.L.; Johnson, D.W.; Mehuys, G.R. Suspended sediment dynamics associated with snowmelt runoff in a small mountain stream of Lake Tahoe (Nevada). Hydrol. Process. 2005, 19, 3569-3580. [CrossRef]

35. Navratil, O.; Evrard, O.; Esteves, M.; Legout, C.; Ayrault, S.; Némery, J.; Mate-Marin, A.; Ahmadi, M.; Lefévre, I.; Poirel, A.; Bonté, P. Temporal variability of suspended sediment sources in an alpine catchment combining river/rainfall monitoring and sediment fingerprinting. Earth Surf. Proc. Land. 2012, 37, 828-846. [CrossRef]

36. Tuset, J.; Vericat, D.; Batalla, R. Rainfall, runoff and sediment transport in a Mediterranean mountainous catchment. Sci. Total Environ. 2016, 540, 114-132. [CrossRef] [PubMed]

37. López-Tarazón, J.A.; Batalla, R.J. Dominant discharges for suspended sediment transport in a highly active Pyrenean river. J. Soil. Sediment. 2014, 14, 2019-2030. [CrossRef]

38. Gentile, F.; Bisantino, T.; Corbino, R.; Milillo, F.; Romano, G.; Trisorio Liuzzi, G. Monitoring and analysis of suspended sediment transport dynamics in the Carapelle torrent (southern Italy). Catena 2010, 80, 1-8. [CrossRef]

39. Ritter, J.R.; Brown, W.M., III. Turbidity and Suspended-Sediment Transport in the Russian River Basin; Open-File Report 72-316; United States Geological Survey: Menlo Park, CA, USA, 1971; pp. 15-29.

40. Doomen, A.; Wijma, E.; Zwolsman, J.J.; Middelkoop, H. Predicting suspended sediment concentrations in the Meuse River using a supply-based rating curve. Hydrol. Process. 2008, 22, 1846-1856. [CrossRef]

41. Birgand, F.; Lefrancois, T.; Grimaldi, C.; Novince, E.; Gilliet, N.; Odoux, C.G. Mesure des flux et échantillonnage des matières en suspension sur de petits cours déau. Ingénieries 2004, 40, 21-35.

42. Vongvixay, A.; Grimaldi, C.; Dupas, R.; Fovet, O.; Birgand, F.; Gilliet, N.; Gascuel-Odoux, C. Contrasting suspended sediment export in two small agricultural catchments: Cross-influence of hydrological behaviour and landscape degradation or stream bank management. Land Degrad. Dev. 2018, 29, 1385-1396. [CrossRef]

43. Evrard, O.; Navratil, O.; Ayrault, S.; Ahmadi, M.; Némery, J.; Legout, C.; Lefévre, I.; Poirel, A.; Bonté, P.; Esteves, M. Combining suspended sediment monitoring and fingerprinting to determine the spatial origin of fine sediment in a mountainous river catchment. Earth Surf. Proc. Land. 2011, 36, 1072-1089. [CrossRef]

44. Navratil, O.; Esteves, M.; Legout, C.; Gratiot, N.; Nemery, J.; Willmore, S.; Grangeon, T. Global uncertainty analysis of suspended sediment monitoring using turbidimeter in a small mountainous river catchment. J. Hydrol. 2011, 398, 246-259. [CrossRef]

45. Vericat, D.; Batalla, R.J.; Gibbins, C.N. Sediment entrainment and depletion from patches of fine material in a gravel-bed river. Water Resour. Res. 2008, 44, W11415. [CrossRef] 
46. López-Tarazón, J.A.; Batalla, R.; Vericat, D.; Francke, T. Suspended sediment transport in a highly erodible catchment: the River Isábena (Southern Pyrenees). Geomorphology 2009, 109, 210-221. [CrossRef]

47. Bisantino, T.; Bingner, R.; Chouaib, W.; Gentile, F.; Trisorio Liuzzi, G. Estimation of runoff, peak discharge and sediment load at the event scale in a medium-size Mediterranean watershed using the AnnAGNPS model. Land Degrad. Dev. 2015, 26, 340-355. [CrossRef]

48. García-Rama, A.; Pagano, S.G.; Gentile, F.; Lenzi, M.A. Suspended sediment transport analysis in two Italian instrumented catchments. J. Mt. Sci. 2016, 13, 957-970. [CrossRef]

49. Haschenburger, J.K. A probability model of scour and fill depths in gravel-bed channels. Water Resour. Res. 1999, 35, 2857-2869. [CrossRef]

50. Moriasi, D.N.; Arnold, J.G.; Van Liew, M.W.; Bingner, R.L.; Harmel, R.D.; Veith, T.L. Model evaluation guidelines for systematic quantification of accuracy in watershed simulations. Trans. ASABE 2007, 50, 885-900. [CrossRef]

51. Vericat, D.; Batalla, R.J. Sediment transport from continuous monitoring in a perennial Mediterranean stream. Catena 2010, 82, 77-86. [CrossRef]

52. Collins, A.L.; Walling, D.E. Fine-grained bed sediment storage within the main channel systems of the Frome and Piddle catchments, Dorset, UK. Hydrol. Process. 2007, 21, 1448-1459. [CrossRef]

53. Walling, D.E.; Owens, P.N.; Leeks, G.J. The role of channel and floodplain storage in the suspended sediment budget of the River Ouse, Yorkshire, UK. Geomorphology 1998, 22, 225-242. [CrossRef]

54. Walling, D.E.; Collins, A.L.; Jones, P.A.; Leeks, G.J.L.; Old, G. Establishing fine-grained sediment budgets for the Pang and Lambourn LOCAR catchments, UK. J. Hydrol. 2006, 330, 126-141. [CrossRef]

55. López-Tarazón, J.A.; Batalla, R.J.; Vericat, D.; Balasch, J. Rainfall, runoff and sediment transport relations in a mesoscale mountainous catchment: The River Isábena (Ebro basin). Catena 2010, 82, 23-34. [CrossRef]

56. Bhosekar, A.; Ierapetritou, M. Advances in surrogate based modeling, feasibility analysis and optimization: A review. Comput. Chem. Eng. 2017, 108, 250-267. [CrossRef]

(C) 2019 by the authors. Licensee MDPI, Basel, Switzerland. This article is an open access article distributed under the terms and conditions of the Creative Commons Attribution (CC BY) license (http://creativecommons.org/licenses/by/4.0/). 